TITLE:

\title{
Territorial Tax Reform and Profit Shifting by US and Japanese Multinationals
}

AUTHOR(S):

Hasegawa, Makoto

CITATION:

Hasegawa, Makoto. Territorial Tax Reform and Profit Shifting by US and Japanese Multinationals. KIER Discussion Paper 2019, 1016: 1-39

ISSUE DATE:

2019-12

URL:

http://hdl.handle.net/2433/245576

RIGHT: 


\title{
KIER DISCUSSION PAPER SERIES
}

\author{
KYOTO INSTITUTE \\ OF \\ ECONOMIC RESEARCH
}

Discussion Paper No.1016

"Territorial Tax Reform and Profit Shifting by US and

Japanese Multinationals"

Makoto Hasegawa

December 2019

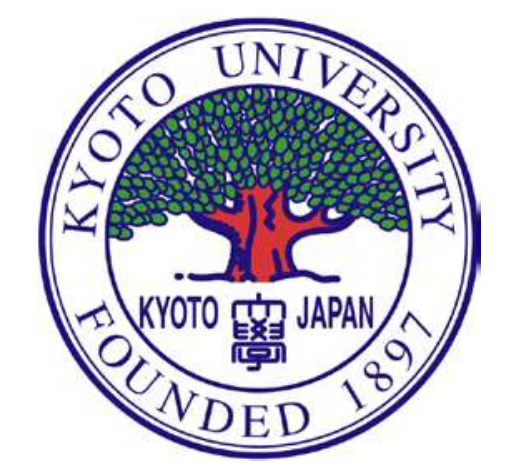

KYOTO UNIVERSITY

KYOTO, JAPAN 


\title{
Territorial Tax Reform and Profit Shifting by US and Japanese Multinationals*
}

\author{
Makoto Hasegawa ${ }^{\dagger}$
}

December 2019

\begin{abstract}
In 2009, Japan began to exempt dividends paid by Japanese-owned foreign subsidiaries to their parent firms from home-country taxation. This tax reform switched Japan's corporate tax system to a territorial tax system that exempts foreign income from home-country taxation. In this paper, I examine the impact of the territorial tax reform on the profit-shifting behavior of Japanese multinationals. I analyze the change in the sensitivity of the reported profits of Japanese-owned foreign subsidiaries to host countries' corporate income tax rates after the tax reform, using US-owned foreign subsidiaries as a comparison group. I find that, on average, the profits of US-owned foreign subsidiaries are more sensitive to host countries' tax rates than are those of Japanese-owned foreign subsidiaries over the whole study period from 2004 to 2016 and over the subperiod from 2004 to 2007, when both countries used the worldwide tax system. However, the sensitivity of the pre-tax profits of Japanese-owned foreign subsidiaries, particularly large subsidiaries, to host countries' corporate tax rates significantly increased in response to the announcement of the territorial tax regime in 2008, relative to that of the US-owned foreign subsidiaries. This suggests that the introduction of the territorial tax system facilitated profit shifting by Japanese multinationals.
\end{abstract}

Keywords: International taxation; Multinational corporations; Profit shifting; Worldwide tax system; Territorial tax system

JEL classification: $\mathrm{H} 25 ; \mathrm{H} 26 ; \mathrm{F} 23$

${ }^{*}$ I appreciate the helpful comments and suggestions of David Agrawal, Kimberly Clausing, Andreas Haufler, James Hines, Molly Saunders-Scott, Hitoshi Shigeoka, Yoshito Takasaki, Kenichi Ueda, Shih-Ying Wu, Junichi Yamasaki, along with the participants at the 2018 National Tax Association Annual Conference, the Japan-Taiwan Seminar on Public Finance at National Chengchi University, and the seminars at the University of Tokyo and Kobe University. I gratefully acknowledge the financial support of the Japan Society for the Promotion of Science (JSPS) (Grant KAKENHI Numbers JP17K13748, JP18H00866, and JP16H03610) and the Nomura Foundation. I would like to thank the Joint Usage and Research Center at the Kyoto Institute of Economic Research for providing me with access to the Orbis database. The usual disclaimers apply.

${ }^{\dagger}$ Graduate School of Economics, Kyoto University. E-mail: mhasegawa@econ.kyoto-u.ac.jp. 


\section{Introduction}

Multinational corporations operate through foreign subsidiaries and branches in countries with different corporate income tax rates and thus, have incentives to shift profits from high- to low-tax jurisdictions to minimize the global tax liabilities of their business groups. They can do this using intrafirm transactions among related parties (parent and foreign subsidiaries), including the manipulation of transfer prices, ${ }^{1}$ intercompany loans,${ }^{2}$ and the transfer of intangible assets within the multinational group. ${ }^{3}$ Profit shifting by multinational corporations has become an important policy issue around the world, with policy makers concerned that profit shifting and excessive tax avoidance by multinational corporations will erode the tax base for corporate income taxation and reduce tax revenue. In response to this concern, the Organisation for Economic Co-operation and Development (OECD) launched the so-called Base Erosion and Profit Shifting (BEPS) project, which proposed an action plan to combat BEPS (OECD, 2015). ${ }^{4}$

As well as corporate tax rates, the design of the international tax system regarding how to tax foreign-source income affects various aspects of multinationals' business activities, including profit shifting. Prior to 2009, Japan had taxed the foreign profits of Japanese multinationals upon repatriation (i.e., when these profits were brought back to Japan) while providing tax credits for the taxes paid to foreign governments. This kind of tax system is referred to as a worldwide tax system. However, in 2009, Japan began to exempt dividends paid by Japanese-owned foreign subsidiaries to their parent firms from home-country taxation, after the details of this reform plan were announced in 2008. This tax reform switched Japan's worldwide tax system to a territorial tax system that exempts foreign income from home-country taxation.

I examine the impact of Japan's territorial tax reform on the profit-shifting behaviors of Japanese multinationals by analyzing the response of the reported profits of Japaneseowned foreign subsidiaries to the tax incentive for profit shifting provided by host countries'

\footnotetext{
${ }^{1}$ For example, when a parent company in a high-tax country imports (exports) goods or services from its foreign subsidiary in a low-tax country, the parent could shift profit to the low-tax subsidiary by setting higher (lower) prices on imported (exported) goods and services (Clausing, 2003; Cristea and Nguyen, 2016; Liu et al., forthcoming).

${ }^{2}$ Because interest payments are generally deductible from taxable income, if a parent company in a lowtax country finances investment in its foreign subsidiary in a high-tax country with debt, interest payments from the high-tax subsidiary to the low-tax parent would shift profits from the subsidiary to the parent (Desai et al., 2004; Huizinga et al., 2008).

${ }^{3}$ Firm-specific intangible assets make it difficult to determine the appropriate arm's-length prices for goods and services produced intensively using intangible assets (e.g., patents and licenses) and allow significant room for the manipulation of transfer prices and profit shifting (Dischinger and Riedel, 2011).

${ }^{4}$ OECD (2015) cites estimates that $4-10 \%$ of the global corporate income tax revenue (USD 100-240 billion) is lost as a result of BEPS.
} 
corporate tax rates, and the introduction of the territorial tax system. Because this tax reform drastically changed the way in which the foreign income of Japanese multinationals was taxed, and also because the three major capital exporting-countries (Japan, the UK, and the US) have recently adopted territorial tax systems, it is important to understand the impact of territorial tax reform on corporate activities, including profit shifting, from the perspective of both the academic literature and the policy debate. ${ }^{5}$ Under a territorial tax system, foreign income is taxed only in the host countries where multinationals' foreign subsidiaries operate. Thus, under this system, multinationals care more about the tax rates of the host countries and have stronger incentives to shift more profits to low-tax jurisdictions to reduce their foreign tax liabilities than is the case under a worldwide tax system.

Although many studies attempt to estimate the extent of profit shifting by multinationals in response to corporate tax rates, ${ }^{6}$ very few studies examine the impact of a switch in the international tax system on multinationals' profit shifting. The exceptions are Markle (2016) and Liu et al. (forthcoming). ${ }^{7}$ Using panel data on parents and their foreign subsidiaries domiciled in 34 countries from 2004 to 2008, Markle (2016) finds that multinationals domiciled in countries that employ territorial tax systems shift more profits than do multinationals domiciled in countries that employ worldwide tax systems. Liu et al. (forthcoming) analyze the intrafirm export transactions of UK multinationals and find that transfer mispricing for the purpose of tax avoidance (underpricing goods exported to low-tax foreign subsidiaries) increased after the UK territorial tax reform in $2009 .^{8}$ However, no studies investigate the consequence of Japan's adoption of the territorial tax regime for multinationals' profit shifting.

I fill this gap in the literature by providing the first evidence on the profit-shifting response

\footnotetext{
${ }^{5}$ The UK and the US adopted territorial tax regimes in 2009 and 2018, respectively. Dharmapala (2018) discusses possible consequences of the US tax reform and other provisions enacted under the Tax Cut and Jobs Act (TCJA) of 2017 in the US. Clausing (2019) assesses the impact of the corporate tax cut and the "Global Intangible Low-Taxed Income" (GILTI) tax under the TCJA on profit shifting and tax base.

${ }^{6}$ As surveyed by Dharmapala (2014), the seminal works on this topic are by Grubert and Mutti (1991) and Hines and Rice (1994), followed by Huizinga and Leaven (2008), Dischinger and Riedel (2011), Dischinger et al. (2014), Riedel et al. (2015), Saunders-Scott (2015), and Dowd et al. (2017). Dharmapala and Riedel (2013) invent the alternative approach in which they identify profit shifting by investigating how exogenous positive earnings shocks to the parent firm propagate to its own affiliates in low-tax countries (relative to those in high-tax countries).

${ }^{7}$ Motivated by the territorial tax reforms of Japan and the UK in 2009, several studies have examined the impacts of the territorial tax system on the activities of multinationals other than profit shifting, including profit repatriation (Egger et al., 2015; Hasegawa and Kiyota, 2017), cross-border mergers and acquisitions (Feld et al., 2016), domestic investment and dividend payouts (Arena and Kutner, 2016), foreign investment (Liu, forthcoming), foreign cash holding (Xing, 2018), and firm value (Bradley et al., 2018).

${ }^{8}$ Consistent with the finding of Liu et al. (forthcoming), Langenmayr and Liu (2019) find that the profitability of UK-owned foreign subsidiaries located in low-tax countries increased after the territorial tax reform.
} 
of Japanese multinationals to the territorial tax reform. Before 2009, Japan used a worldwide tax system similar to that used in the US and, at that time, both countries set tax rates at around 40\%, which were the highest rates among the OECD member countries. Japan has switched to a territorial tax regime since 2009, whereas the US continued to employ a worldwide tax system from 2009 to 2017. I construct panel data on Japanese- and US-owned foreign subsidiaries from 2004 to 2016. Then, I examine how the sensitivity of the pretax profits of Japanese-owned foreign subsidiaries to host countries' corporate income tax rates changed due to the tax reform, using US-owned foreign subsidiaries as a comparison group.

I find that the profits of US-owned foreign subsidiaries are, on average, more sensitive to host countries' tax rates compared with those of Japanese-owned foreign subsidiaries. The semi-elasticity of pre-tax profits with respect to host countries' corporate tax rates (referred to as the "tax semi-elasticity") is larger for US-owned foreign subsidiaries than for Japaneseowned foreign subsidiaries over the whole study period from 2004 to 2016 and also for the subperiod from 2004 to 2007, when both countries used the worldwide tax system. This suggests that the average Japanese-owned foreign subsidiary engaged in profit shifting to a lesser extent than did the average US-owned foreign subsidiary.

However, the sensitivity of the pre-tax profits for Japanese-owned foreign subsidiaries, particularly for large subsidiaries, to host countries' corporate tax rates sharply increased in response to the announcement of the territorial tax regime in 2008, relative to that for US-owned foreign subsidiaries. As a result, the tax semi-elasticity of pre-tax profits for Japanese-owned subsidiaries was larger than that for US-owned subsidiaries from 2008 to 2012. Considering that there were no drastic changes in other tax provisions in Japan that could affect the profit-shifting behavior of Japanese multinationals, including the Controlled Foreign Corporations (CFC) rules, over the same period, these results suggest that the introduction of the territorial tax system facilitated profit shifting by Japanese multinationals.

The rest of the paper is organized as follows. Section 2 describes Japan's territorial tax reform in 2009 and its expected impact on profit shifting by Japanese multinationals. Section 3 explains the data used for the empirical analysis. Section 4 explains the baseline estimation method. Section 5 conducts the preliminary analysis to obtain a broad perspective on the profit-shifting behavior of US and Japanese multinationals. Section 6 examines the change in the extent of profit shifting by Japanese multinationals in response to the tax reform. Section 7 checks the robustness of the main results presented in Section 6 using alternative specifications. Section 8 concludes. 


\section{Japan's Territorial Tax Reform and the Expected Impact on Profit Shifting}

Under the worldwide tax system that prevailed in Japan until 2008, the Japanese government taxed the foreign-source income of multinational corporations upon repatriation, while providing tax credits for corporate taxes paid and other related taxes paid to host-country governments. For example, consider that a parent company in Japan with a corporate income tax rate of $40 \%$ owns a subsidiary in Singapore with a corporate income tax rate of $18 \%$. Suppose that the subsidiary earns $\$ 100$ and then remits the after-tax profit of $\$ 82$ to the Japanese parent via dividends, after paying the corporate income tax of $\$ 18$ to the Singapore government. Under the worldwide tax system, the Japanese government imposes the $40 \%$ corporate income tax on the pretax income of $\$ 100$ when the parent receives dividends of $\$ 82$. Then, the tax liability of the parent is $\$ 40$, but it can claim foreign tax credits for the corporate income tax of $\$ 18$ paid by the subsidiary to the Singapore government. Thus, the net tax liability in Japan is $\$ 22(=40-18)$. The total tax liability for the multinational in these two countries is $\$ 40, \$ 22$ in Japan and $\$ 18$ in Singapore. ${ }^{9}$ However, the Japanese government became concerned that, under the worldwide tax system, Japanese multinationals were retaining abroad the profits earned by their foreign subsidiaries to avoid additional taxation in Japan.

To stimulate dividend repatriations from Japanese-owned foreign subsidiaries in the hope that the repatriated dividends would be used for domestic investment and employment, the Japanese government began seriously to consider changing its system of worldwide taxation. On May 9, 2008, the government announced that it had examined implementation of a territorial tax system under the tax reform for 2009. ${ }^{10}$ The Ministry of Economy, Trade, and Industry of Japan (METI) released the interim report that described the details on the design of a territorial tax system on August 22, 2008 (METI, 2008). Following the METI's report, the proposals for adopting a territorial tax regime were sequentially approved and released by the Government Tax Commission on November 28, 2008, the Liberal Democratic Party (the ruling party in the Japanese House of Representatives) on December 12, 2008, the Ministry of Finance on December 19, 2008, and the Cabinet on January 23, 2009. Finally,

\footnotetext{
${ }^{9}$ If the host country's tax rate is higher than Japan's tax rate, the foreign tax liability could exceed that in Japan. Then, the parent earns foreign tax credits that exceed the Japanese tax liability upon repatriation. In this case, the parent can use the foreign tax credits to completely offset the Japanese tax liability. The residual foreign tax credits can be used to reduce the tax liabilities on foreign-source income earned within the next 3 years.

${ }^{10}$ At the interview immediately after the Cabinet meeting on May 9, 2008, Akira Amari, the Minister of Economy, Trade, and Industry of Japan announced that he had instructed his ministry to consider implementing a territorial tax regime under the 2009 tax reform (Bradley et al., 2018).
} 
the legislative bill including the territorial tax reform was passed into law on March 27, 2009 and came into effect on April 1, 2009 (Bradley et al., 2018). ${ }^{11}$

The Japanese version of a territorial tax regime, which is referred to as a dividend exemption system, exempts $95 \%$ of dividends paid by Japanese-owned foreign subsidiaries to their parents from home-country taxation under the tax reform of 2009. ${ }^{12}$ This tax reform has effectively switched the Japanese corporate tax system from a worldwide tax system to a territorial tax system that exempts foreign-source income from home-country taxation. ${ }^{13}$

Under Japan's territorial tax system (or dividend exemption system), only $5 \%$ of repatriated dividends are taxed by the Japanese government. In the above example, if the Singapore subsidiary remits dividends of $\$ 82$ to the Japanese parent, the tax liability in Japan is $\$ 1.64$ $(=0.05 \times 82 \times 0.4)$, which is much lower than the repatriation tax of $\$ 22$ under the previous worldwide tax system. The total tax liability on $\$ 100$ of foreign income under the new system is $\$ 19.64$ (\$1.64 in Japan and $\$ 18$ in Singapore), whereas it was $\$ 40$ under the previous worldwide tax system. In this way, the territorial tax reform of 2009 reduced the tax burden on the foreign earnings of Japanese multinationals.

This tax reform could alter the multinationals' incentives for profit shifting. Under the worldwide tax system that was in place before 2009, if a Japanese-owned foreign subsidiary earned profits in a low-tax country such as Singapore and remitted them to the parent in Japan, the parent faced additional Japanese taxation, and the total effective tax rate on foreign earning became the same as the Japanese tax rate, regardless of the foreign tax rates. By contrast, under the territorial tax system, foreign income is taxed only in the host country because their foreign income repatriated via dividends is exempt from taxation in Japan (except for the Japanese tax on $5 \%$ of the dividends). Thus multinationals can reduce their tax payments by earning profits in lower-tax countries. As a result, multinationals should have stronger incentives to establish their subsidiaries in low-tax countries and, given the location decisions of foreign subsidiaries, to shift more profits to existing subsidiaries in low-tax countries. ${ }^{14}$

\footnotetext{
${ }^{11}$ Because the Japanese government announced this tax reform in May 2008 and the detailed information on the territorial tax regime was publicly known in August 2008, it could be possible that Japanese multinationals responded to the tax reform and changed their behaviors during fiscal year 2008, expecting the enactment of the new tax regime in April 2009.

${ }^{12}$ The remaining $5 \%$ of dividends are not exempt from Japanese taxation. The tax law assumes that multinationals deducted interest and other expenses from their taxable income when they invested in foreign subsidiaries. Those expenses are assumed to correspond to $5 \%$ of repatriated dividends and thus are not allowed to be deducted twice.

${ }^{13}$ Note that the exemption applies only to repatriated dividends. Other types of foreign income, including royalties and interest paid by foreign subsidiaries to Japanese parents, foreign capital gains, and profits of foreign branches, are still taxed by the Japanese government.

${ }^{14}$ Barrios et al. (2008) find that a one percentage point higher repatriation tax rate reduces the probability of a subsidiary being located in the host country by 1.07 percentage points. Under the worldwide tax system,
} 


\section{Data}

In the following sections, I empirically examine whether and how the profit-shifting behavior of Japanese multinationals has changed with the enactment of the territorial tax system, using financial information on Japanese-owned foreign subsidiaries. For this purpose, I collected financial information on profit and loss statements and balance sheets for Japanese-owned foreign subsidiaries from 2004 to 2016 from the Orbis database, which is provided by Bureau van Dijk (BvD). A Japanese-owned foreign subsidiary is defined as a company located outside Japan, more than $50.1 \%$ of which is owned by a Japanese parent, which Orbis refers to as a "global ultimate owner (GUO)" resident in Japan. A GUO is a company of which more than $50.1 \%$ is not owned by any other company or whose owner is unknown.

I use the two hard disk drive versions of Orbis released in 2013 and 2017. Each version of Orbis contains the previous 10 years' information. I collected the financial information for 2008-2016 from the 2017 version of Orbis and that for 2004-2007 from the 2013 version of Orbis. When I collected the financial information on foreign subsidiaries for 2008-2016 (2004-2007), I searched for foreign subsidiaries for which there was information available on pre-tax profit, fixed assets, and employee compensation-required for all specifications in the analysis - for at least 1 year during 2008-2016 (2004-2007). Then, I merged the two data sets using the unique identification code for each subsidiary, its BvD ID, as a key. ${ }^{15}$ When I merged the data for 2004-2007 and that for 2008-2016, I retained foreign subsidiaries in the sample that were in both data periods because of my interest in analyzing the change in the profit-shifting behavior of Japanese multinationals after the 2009 tax reform. ${ }^{16}$

As described in more detail in the next section, I use US-owned foreign subsidiaries as a

the repatriation tax rate is proportional to the tax differential between the home and host countries, which is $22 \%$ for the Singapore subsidiary in the above example, and thus becomes higher when the host country's tax rate is lower. Therefore, Barrios et al.'s (2008) result implies that the territorial tax reform, which eliminates the repatriation tax, might give Japanese multinationals an incentive to choose low-tax countries as the location for their investment.

${ }^{15}$ For a few countries (e.g., Italy), BvD IDs changed between the two versions of Orbis and thus, could not serve as a key variable to merge the two data sets. In that case, I used the company name, country of residence, four-digit industry code, and the date of incorporation as key variables to merge the financial information of foreign subsidiaries obtained from the two versions of Orbis.

${ }^{16}$ Indeed, the 2017 version of Orbis (2008-2016 data) has basic financial data on more subsidiaries than does the earlier 2013 version of Orbis (from which the 2004-2007 data were collected). In part, this is because the coverage of foreign subsidiaries in Orbis has expanded over time. It may also be because the number of foreign subsidiaries has increased in recent years. If the foreign subsidiaries that appear only in the 2008-2016 data are added to the sample, the sample size is enlarged, but the panel data set becomes heavily unbalanced. Moreover, using these extended data sets may result in capturing the location choices of multinationals in response to the tax reform, rather than being able to focus solely on the profit-shifting incentives, taking the location decisions as given. Therefore, I use a panel data set that consists of the foreign subsidiaries that exist and that report basic financial information in both data sets. 
comparison group to evaluate the change in the tax sensitivity of Japanese multinationals' reported profits around the time of the Japanese territorial tax reform. Thus, I collected the financial information of US-owned foreign subsidiaries from 2004 to 2016 using the same procedures as for the Japanese-owned foreign subsidiaries. By appending the US-owned subsidiary data to the Japanese data, I constructed the panel data set of Japanese- and US-owned foreign subsidiaries. From this sample, I removed the foreign subsidiaries in the financial, real estate, and public administration sectors, and those owned by parents in these sectors, because the tax treatment and incentives for profit shifting are quite different in these sectors compared with others. To capture the profit-shifting incentive for each sole subsidiary, I need to use the unconsolidated financial information. Thus, I removed subsidiaries for which unconsolidated accounts were not available. The information on corporate income tax rates is obtained from KPMG's Tax Rates Online. Macroeconomic variables, including gross domestic product (GDP) per capita, population, unemployment rates, and annual GDP growth rates of host countries are obtained from the World Bank's World Development Indicators.

The final data consist of 97,183 US-owned subsidiary-year observations and 28,625 Japaneseowned subsidiary-year observations, for which information on pre-tax profit, fixed assets, employment compensation, and the host country's tax rate is available. Table 1 summarizes the distribution of those subsidiaries across jurisdictions. Note that the distribution of the subsidiaries is similar between the Japanese and US multinationals, and is heavily skewed to European countries for both US and Japanese multinationals. This is because the coverage of the Orbis database is better for European countries. ${ }^{17}$ Table 2 provides the summary statistics of financial and macroeconomic variables used in the empirical analysis for US-owned subsidiaries, Japanese-owned subsidiaries, and all subsidiaries.

\section{Estimation Method}

This section explains the baseline empirical specifications for analyzing the profit-shifting behavior of multinational corporations and the profit-shifting response of Japanese multinationals to the 2009 tax reform. A large body of literature measures the extent of profit shifting by multinationals using the methodology invented by Hines and Rice (1994), referred

\footnotetext{
${ }^{17}$ One limitation on the use of the Orbis database is that it lacks the financial information on foreign subsidiaries in Asian jurisdictions (e.g., China, Hong Kong, Indonesia, Malaysia, Singapore, South Korea, Taiwan, Thailand, and Vietnam), where Japanese multinationals intensively invest and locate many subsidiaries. Another limitation is that, as Clausing (2019) points out, it lacks the financial information on foreign subsidiaries in tax havens.
} 
to as the Hines-Rice approach by Dharmapala (2014). ${ }^{18}$ The key idea of this approach is to decompose the pre-tax profit of a foreign subsidiary into the "true profit," which is generated from the actual business activities of the subsidiary (unrelated to profit-shifting activities), and the "shifted profit," which is the profit shifted in and out of the foreign subsidiary in response to tax incentives for the purpose of tax avoidance. To investigate tax-motivated profit shifting, researchers are interested in examining the response of the shifted profit to the corporate tax rate.

The challenge is that researchers can observe only the pre-tax profit; they cannot observe the true profit and the shifted profit separately. Hines and Rice (1994) tackle this problem by assuming that the true profit is a Cobb-Douglas function of labor and capital inputs and imposing some other assumptions on the costs of profit shifting. ${ }^{19}$ They show that, under these assumptions, the logarithm of the subsidiary's pre-tax profit can be expressed as a linear function of the host country's tax rate and the logarithms of capital and labor inputs. Then, by regressing the pre-tax profit on the corporate tax rate while including proxies for capital and labor inputs as control variables, we can estimate the response of the shifted profit to corporate tax rates, holding the true profit fixed, which is deemed to indicate the extent of tax-motivated profit shifting.

The baseline regression equation that incorporates the above idea, and can be estimated using fixed-effects ordinary least squares (OLS), is expressed as follows.

$$
\ln \pi_{i t}=\alpha_{i}+\beta \operatorname{Tax}_{i t}+\alpha_{1} \ln K_{i t}+\alpha_{2} \ln L_{i t}+\boldsymbol{X}_{i t} \gamma^{\prime}+\text { Industry }_{i} \times \text { Year }_{t}+u_{i t},
$$

where $\pi_{i t}$ represents the pre-tax profit of foreign subsidiary $i$ in year $t$. Subsidiary $i$ 's capital inputs are represented by $K_{i t}$ and proxied by fixed assets. Its labor inputs are represented by $L_{i t}$ and proxied by employment compensation. The log transformation is applied to these variables in the above equation. ${ }^{20}$ The key independent variable is $\operatorname{Tax}_{i t}$, which represents the host country's statutory corporate income tax rate faced by subsidiary $i$ in year $t$.

The vector of country-level control variables, $\boldsymbol{X}_{i t}$, includes the log of GDP per capita, the log of total population, the unemployment rate, and the annual GDP growth rate of the host country in year $t$. These variables are intended to capture the impacts on the

\footnotetext{
${ }^{18}$ See footnote 6 for the list of studies that use this approach. Hines and Rice (1994) use the cross-sectional financial data of US-owned foreign subsidiaries aggregated at the country-level, whereas recent studies tend to use firm-level panel data.

${ }^{19}$ Hines and Rice (1994) assume that the costs of profit shifting increase in the amount of profits shifted in a quadratic manner and are deductible from taxable income.

${ }^{20}$ Because the dependent variable is the natural logarithm of the subsidiary's pre-tax profit, subsidiaryyear observations with losses will be excluded from the regression samples in the following sections. This treatment is consistent with the literature on profit shifting listed in footnote 6 and enables me to compare the estimates of this paper with those of the previous studies.
} 
subsidiary's profit of the country's affluence (proxied by the GDP per capita), market size (proxied by total population), macroeconomic conditions (proxied by the unemployment rate), and investment opportunities (proxied by the annual GDP growth rate). ${ }^{21}$ The set of dummy variables that indicate the one-digit industry code to which subsidiary $i$ belongs is denoted by Industry. The set of year dummy variables is denoted by $Y$ ear ${ }_{t}$. The interaction terms of these two sets of dummy variables $\left(\right.$ Industry $_{i} \times$ Year $\left._{t}\right)$ are included in equation (1) to capture the effects of industry-specific shocks for each year on the subsidiary's profit. The subsidiary fixed effects, denoted by $\alpha_{i}$, control for all time-invariant factors specific to subsidiary $i$ that affect the subsidiary's profit. The error term is $u_{i t}$.

The estimated coefficient $\beta$ indicates the percentage change in pre-tax profits in response to a one percentage point increase in corporate tax rates. A negative estimate of $\beta$ is consistent with tax-motivated profit shifting. Many studies consistently find negative estimates for $\beta$, suggesting that a higher tax rate reduces reported income as a result of profit shifting. The absolute value of $\beta$ is the semi-elasticity of subsidiary pre-tax profits with respect to corporate tax rates. Heckemeyer and Overesch (2017) conduct a meta-regression analysis using 203 estimates from 27 papers and suggest that a consensus (average) estimate of the semi-elasticity is about 0.8. Beer et al. (2018) conduct similar meta-regressions including more recent studies and find that the consensus semi-elasticity is around one and is larger in recent years.

To obtain a broad perspective of the profit-shifting behavior of US and Japanese multinationals, I first estimate equation (1) separately for each of Japanese-owned and US-owned foreign subsidiary groups over the entire data period from 2004 to 2016 and analyze the tax semi-elasticity of reported profits for each of the two subsidiary groups. Then, I examine the possibility that the profit-shifting behavior could be heterogeneous depending on firm characteristics (size and intangible intensity), as detailed later.

I will investigate in Section 6 whether the enactment of the territorial tax regime facilitated the profit shifting by Japanese multinationals. To address this research question, I examine whether the tax semi-elasticity of reported profits for Japanese-owned foreign subsidiaries increased in response to the tax reform. As discussed in Section 2, the Japanese government made a credible announcement about the introduction of a territorial tax regime in May 2008 and released detailed information on the design of the new system in August 2008. Therefore, Japanese multinationals possibly started to shift more profits to low-tax

\footnotetext{
${ }^{21}$ These macroeconomic variables are commonly used as control variables in the profit-shifting literature (e.g., Dharmapala and Riedel, 2013; Riedel et al., 2015; Dowd et al., 2017). As a robustness check, I included foreign exchange rates of local currencies per USD (normalized to one in 2003) as an additional control variable to capture the effect of the fluctuation of foreign exchange rates on the subsidiary's profit denominated in USD. The results presented in the following sections remained unchanged.
} 
jurisdictions in response to the announcement of the tax reform in 2008, expecting the enactment of the new tax regime in April 2009. ${ }^{22}$

Using the full sample that includes both US- and Japanese-owned foreign subsidiaries, I examine the change in the tax semi-elasticity of pre-tax profits for Japanese-owned subsidiaries relative to that for US-owned subsidiaries by extending the baseline equation (1) as follows.

$$
\begin{aligned}
\ln \pi_{i t} & =\alpha_{i}+\sum_{j=2004}^{2016} \beta_{U S, j} Y_{e a r_{j}} \times U S_{i} \times \operatorname{Tax}_{i t}+\sum_{j=2004}^{2016} \beta_{J P, j} Y_{e a r_{j}} \times J P_{i} \times \operatorname{Tax}_{i t} \\
& +\sum_{j=2004}^{2016} \gamma_{U S, j} Y_{e a r_{j}} \times U S_{i}+\sum_{j=2004}^{2016} \gamma_{J P, j} Y_{e a r_{j}} \times J P_{i} \\
& +\alpha_{1} \ln K_{i t}+\alpha_{2} \ln L_{i t}+\boldsymbol{X}_{i t} \gamma+\text { Industry }_{i} \times \text { Year }_{t}+u_{i t},
\end{aligned}
$$

where $U S_{i}$ is a dummy variable that equals one if subsidiary $i$ is owned by a US parent and zero otherwise, and $J P_{i}$ is a dummy variable that equals one if subsidiary $i$ is owned by a Japanese parent and zero otherwise. $Y_{\text {ear }}$ is the year dummy variable for year $j$, which takes a value of one if $t=j$ and zero otherwise for $j=2004,2005, \ldots, 2016$. In this specification, the absolute value of the estimated coefficient on $Y_{e a r_{j}} \times U S_{i} \times T_{a x}$, or $\left|\beta_{U S, j}\right|$ indicates the tax semi-elasticity for US-owned foreign subsidiaries in year $j$. Similarly, the absolute value of the estimated coefficient on $\operatorname{Year}_{j} \times J P_{i} \times \operatorname{Tax}_{i t}$, or $\left|\beta_{J P, j}\right|$ is the tax semi-elasticity for Japanese-owned foreign subsidiaries in year $j$. To control for the parent-country-specific shocks, including corporate tax policy changes and macroeconomic conditions, I include the set of interaction terms of $Y e a r_{j}$ with $U S_{i}$ and $J P_{i}\left(Y_{e a r_{j}} \times U S_{i}\right.$ and $\left.Y e a r_{j} \times J P_{i}\right)$ for $j=2004,2005, \ldots, 2016 .^{23}$

If Japan's 2009 tax reform facilitated profit shifting by Japanese multinationals, the tax semi-elasticity for Japanese-owned foreign subsidiaries would start to increase relative to that for US-owned foreign subsidiaries in response to the announcement and/or enactment of the territorial tax regime. In Section 6, I will estimate and plot $\beta_{U S, j}$ and $\beta_{J P, j}$ over the data period for $j=2004, \ldots, 2016$ and graphically investigate the change in the tax semi-elasticity

\footnotetext{
${ }^{22}$ If the marginal cost for profit shifting is increasing in the amount of profits shifted, as assumed in the literature, Japanese multinationals would have incentives to reduce the sum of costs for profit shifting over time by starting to shift more profits to low-tax subsidiaries when they learned of the enactment of the territorial tax regime.

${ }^{23}$ Because these interaction terms absorb the effects of the corporate income tax rates of the US and Japan, the estimates of the tax semi-elasticities $\left(\left|\beta_{U S, j}\right|\right.$ and $\left.\left|\beta_{J P, j}\right|\right)$ are unchanged when replacing the host-country tax rate $\left(\operatorname{Tax}_{i t}\right)$ with the tax differential between the parent and the foreign subsidiary in equation (2). In other words, in this specification, I will use the variations in host-country tax rates to estimate the tax semi-elasticities, holding the corporate tax rates of the US and Japan fixed.
} 
for Japanese-owned subsidiaries around 2009. This approach would be useful in accounting for unobservable factors that could affect the tax semi-elasticities for both US and Japanese multinationals, for example, the international pressure on multinationals' profit shifting and tax avoidance imposed by the development of the BEPS project.

US-owned foreign subsidiaries serve as a reasonable comparison group to evaluate the change in the tax semi-elasticity for Japanese-owned foreign subsidiaries caused by the territorial tax reform for the following reasons. First, Japanese multinationals experienced the switch in the international tax system from worldwide taxation to territorial taxation in 2009, whereas US multinationals did not experience such a shift during the data period from 2004 to 2016. Second, both Japan and the US set the highest corporate tax rates among OECD countries, of around 40\%, and both employed worldwide tax regimes before the 2009 tax reform. Moreover, the worldwide tax systems of Japan and the US were quite similar in many respects. In particular, both countries allowed for deferral of taxation on foreign dividends until repatriation (tax deferral) and calculated the maximum amount of foreign tax credits available in each year (foreign tax credit limit) based on the home country's tax liabilities on the total amount of foreign income repatriated at the parent level. ${ }^{24}$ Therefore, even though the magnitude of profit shifting by Japanese and US multinationals may differ prior to the tax reform, the incentive for profit shifting provided by the worldwide tax system would be similar or at least comparable. If the trend in the tax semi-elasticity for Japaneseowned foreign subsidiaries drastically changed around the time of the tax reform relative to that for US-owned subsidiaries, the gap in the trends between the two subsidiary groups would reflect the impact of the tax reform on the profit-shifting behavior of Japanese-owned subsidiaries. ${ }^{25}$

In the following sections, I analyze the profit-shifting behavior of US and Japanese multinationals and the change in the profit-shifting behavior of Japanese multinationals in response to the 2009 tax reform based on regression equations (1) and (2). As appropriate, I extend these specifications and try alternative specifications that will be discussed in detail later.

\footnotetext{
${ }^{24}$ This feature of calculating the foreign tax credit limit allows multinationals to reduce the total tax liabilities on foreign income by offsetting the tax liabilities on foreign income repatriated from low-tax countries with excess foreign tax credits earned by repatriating foreign income from high-tax countries. This tax avoidance method is referred to as cross crediting (Hines, 1999).

${ }^{25}$ Motivated by reasons similar to those underlying this paper, some studies use US multinationals as a comparison group for Japanese multinationals to evaluate the impacts of the Japanese tax system and tax reform. For example, Hines (2001) compares US and Japanese outbound foreign direct investment (FDI) to examine the impact of tax-sparing provisions on Japanese outbound FDI. More recently, Xing (2018) and Bradley et al. (2018) use US multinationals as a comparison group to evaluate the impact of Japan's territorial tax reform on the foreign cash holdings and the investor valuation of Japanese multinationals, respectively
} 


\section{Profit Shifting by US and Japanese Multinationals}

Before focusing on the change in the tax semi-elasticity of pre-tax profits following the tax reform, I begin by estimating the baseline equation (1) separately for US- and Japaneseowned subsidiaries to obtain a broad perspective of their profit-shifting behaviors. Table 3 presents the estimation results. Columns (1) and (2) provide the results when using the sample of US-owned foreign subsidiaries, whereas columns (3) and (4) present the results when using the sample of Japanese-owned foreign subsidiaries. All specifications include the industry-year dummies and subsidiary fixed effects. The macroeconomic control variables are excluded in columns (1) and (3), but included in columns (2) and (4). Standard errors are clustered at the subsidiary level to account for the serial correlation of the error term within subsidiaries, and are shown in parentheses below the estimated coefficients.

For the sample of US-owned foreign subsidiaries, the coefficient on $\operatorname{Tax}_{i t}$ is negative and statistically significant at the $1 \%$ level in both specifications in columns (1) and (2). In the preferred specification that includes macroeconomic control variables in column (2), the semi-elasticity of pre-tax profits with respect to corporate tax rates is 0.74 , suggesting that a one percentage point lower corporate tax rate in the host country increases the subsidiary's reported profit by $0.74 \% .{ }^{26}$ This is consistent with tax-motivated profit shifting and the size of the estimate is close to the consensus semi-elasticity (0.8-1.0) predicted by Heckemeyer and Overesch (2017) and Beer et al. (2018). As expected, the significantly positive coefficients on fixed assets and employment compensation imply that labor and capital inputs contribute to increasing the true profit generated from business activities other than profit shifting. ${ }^{27}$

The estimated coefficient on $\operatorname{Tax}_{i t}$ for Japanese multinationals is quite different from that for US multinationals. In column (3), the estimated coefficient of -1.18 is statistically significant at the $5 \%$ level. However, in the preferred specification that includes time-variant macroeconomic variables in column (4), the coefficient loses statistical significance and its absolute value (semi-elasticity) decreases to 0.28. Compared with the result for US-owned foreign subsidiaries, the tax semi-elasticity of the pre-tax profits of Japanese-owned foreign subsidiaries is small and not statistically significant. These results imply that the reported profits of Japanese multinationals are less sensitive to the tax incentive for profit shifting (measured by host-country tax rates) than are those of US multinationals.

\footnotetext{
${ }^{26}$ The preferred specifications chosen in this paper include the macroeconomic control variables. Corporate tax rates are highly likely to be correlated with macroeconomic conditions and the size of the economy in host countries (Slemrod, 2004). Therefore, excluding these control variables may cause omitted-variable bias.

${ }^{27}$ The estimated coefficients on macroeconomic control variables, including population, unemployment rates, and GDP growth rates, are statistically significant, with the expected signs. These coefficients imply that the pre-tax profits of foreign subsidiaries tend to be larger in countries with larger populations, better labor market conditions, and greater opportunities for investment.
} 
The baseline specifications in Table 3 estimate the tax sensitivity of the pre-tax profits of the average subsidiary. However, the response of reported profits to tax incentives may be heterogeneous depending on firm characteristics. For example, Dischinger and Riedel (2011) show that intangible assets held by foreign subsidiaries facilitate multinationals' profit shifting because the appropriate arm's-length prices for firm-specific patents and licenses produced from intangible assets are hard to determine, which enables multinationals to manipulate prices in intrafirm transactions. Although the average Japanese-owned foreign subsidiary does not strongly respond to the tax incentive for profit shifting, the reported profits of intangible-intensive subsidiaries may be more responsive than those of other subsidiaries. To examine the heterogeneous tax sensitivity of pre-tax profits, I split the full sample of US- and Japanese-owned foreign subsidiaries into two subgroups: intangible-intensive subsidiaries and nonintangible-intensive subsidiaries. The subsidiary's intangible intensity is defined as the mean of the ratio of intangible fixed assets to total assets in each year over the sample period. ${ }^{28}$ The median of the intangible intensity for the full sample including both US- and Japanese-owned subsidiaries is 0.0014. I classify subsidiaries with intangible intensities that are greater than this value into the intangible-intensive group, and other subsidiaries into the nonintangible-intensive group. ${ }^{29}$

Table 4 presents the estimation results for equation (1) when the US and Japanese samples are split into the intangible-intensive and nonintangible-intensive groups. The results for the sample of US-owned foreign subsidiaries are shown in columns (1) and (2), and those for the Japanese-owned foreign subsidiaries are shown in columns (3) and (4). Columns (1) and (3) show the results for the nonintangible-intensive group, whereas columns (2) and (4) show the results for the intangible-intensive group. All specifications include macroeconomic control variables, industry-year dummies, and subsidiary fixed effects.

In the US sample, intangible-intensive subsidiaries are more sensitive to the tax incentive for profit shifting than are other subsidiaries. The estimated semi-elasticity of pre-tax profits for intangible-intensive subsidiaries, presented in column (2), is 1.38 and statistically significant at the $1 \%$ level. This is larger than the semi-elasticity for nonintangible-intensive subsidiaries, which is estimated to be insignificant at 0.11 , as shown in column (1). This result is consistent with the finding of Dischinger and Riedel (2011) and suggests that intangibleintensive US-owned subsidiaries shift out more profits when facing higher tax rates than do

\footnotetext{
${ }^{28}$ For example, if subsidiary $i$ reports both intangible fixed assets and total assets for all years from 2004 to 2016, the intangible intensity of subsidiary $i$ is defined by $\frac{1}{13} \sum_{t=2004}^{2016} \frac{\text { Intangible Fixed Assets }_{i t}}{\text { Total Assets }_{i t}}$, where Intangible Fixed Assets $_{i t}$ and Total Assets $i t$ are subsidiary $i$ 's intangible fixed assets and total assets in year $t$, respectively.

${ }^{29}$ To compare directly the response of intangible-intensive subsidiaries between the US and Japanese samples, I split them based on the same threshold for the intangible intensity.
} 
other subsidiaries. On the other hand, the estimated coefficient on $\operatorname{Tax}_{i t}$ is not statistically significant for either of the two groups of Japanese-owned foreign subsidiaries. However, the semi-elasticity for intangible-intensive subsidiaries is larger (0.64) in column (4) than both that for nonintangible-intensive subsidiaries in column (3) of Table 4 (with the opposite sign) and that for the average subsidiary (0.28) in column (4) of Table 3. Thus, there appears to be a tendency for Japanese-owned foreign subsidiaries with high intangible intensity to be more responsive to the tax incentive for profit shifting than are other subsidiaries.

Next, I examine the heterogeneous tax sensitivity of pre-tax profits, depending on firm size. Profit shifting would entail fixed costs for multinationals such as costs for establishing international tax-planning divisions in foreign subsidiaries and for learning tax practices in host countries. Larger firms are expected to take advantage of scale economies to cover these fixed costs and shift profits successfully by avoiding the regulations regarding transfer pricing rules. ${ }^{30}$ To test this hypothesis, I split the full sample of US- and Japanese-owned foreign subsidiaries into large subsidiaries and small subsidiaries in a manner similar to that used for columns (1)-(4) of Table 4. The subsidiary size is defined as the mean of total assets over the sample period. The median subsidiary size defined in this way for the full sample including both US- and Japanese-owned subsidiaries is 16176.9 thousand USD. I classify subsidiaries with mean total assets that are greater than this value into the large subsidiary group, and other subsidiaries into the small subsidiary group.

The results are provided in columns (5)-(8) of Table 4. Columns (5) and (7) show the results for the small subsidiary group, whereas columns (6) and (8) show those for the large subsidiary group. The estimated semi-elasticity of pre-tax proftis for large US-owned foreign subsidiaries is 0.99 and statistically significant at the $1 \%$ level, as shown in column (6), which is larger than that for small US-owned subsidiaries, estimated to be insignificant at 0.41 in column (5). This suggests that larger subsidiaries are more sensitive to tax incentives for profit shifting, as expected. I find a similar pattern for the estimated coefficient on $\operatorname{Tax}_{i t}$ for Japanese-owned foreign subsidiaries, though not statistically significant. The tax semi-elasticity for large subsidiaries is estimated at 0.65 in column (8), which is larger than that for small subsidiaries, estimated to be 0.15 in column (7). Thus, there appears to be a tendency for large Japanese-owned foreign subsidiaries to be more responsive to the incentive for profit shifting than are small Japanese-owned foreign subsidiaries. ${ }^{31}$

\footnotetext{
${ }^{30}$ This hypothesis can be interpreted in terms of tax compliance costs. Barbone et al. (2012) make the point that small companies incur high tax compliance costs, which include the costs of tax planning. Thus, large subsidiaries would engage in profit shifting, with low compliance costs associated with tax planning.

${ }^{31}$ One concern is that the high tax-sensitivity of large subsidiaries might be derived because large subsidiaries tend to be intangible-intensive. However, there is a low correlation between being in the intangibleintensive group and being in the large subsidiary group. The correlation coefficient is 0.164 for the US sample and 0.109 for the Japanese sample.
} 
In summary, US-owned foreign subsidiaries are, on average, more sensitive to the tax incentive for profit shifting than are Japanese-owned foreign subsidiaries. The pre-tax profits of US-owned foreign subsidiaries, particularly those with high intangible intensity or of large size, exhibit strong responses to host countries' tax rates that are consistent with profit-shifting motives. Similarly, large and intangible-intensive Japanese-owned foreign subsidiaries have larger tax semi-elasticities. However, their magnitude and statistical significance are lower than the tax semi-elasticities for large and intangible-intensive US-owned foreign subsidiaries. The difference in the results for US and Japanese multinationals is possibly the result of Japanese multinationals being less tax aggressive than US multinationals, which is consistent with anecdotal evidence and the arguments of Takashima (2009) and Altshuler et al. (2015). ${ }^{32}$

\section{Change in the Tax Sensitivity of Pre-tax Profits after the Territorial Tax Reform}

In this section, I investigate the change in the profit-shifting behavior of Japanese multinationals after the 2009 territorial tax reform. The hypothesis is that if the territorial tax system facilitates profit shifting by Japanese multinationals, the tax semi-elasticity of pretax profits should increase after the tax reform. To test this hypothesis, I first estimate the regression equation (2) and calculate the tax semi-elasticity of pre-tax profits for USand Japanese-owned foreign subsidiaries in each year from 2004 to 2016 . The key parameters of interest are the coefficient on the interaction term of $\operatorname{Year}_{j} \times U S_{i} \times \operatorname{Tax}_{i t}\left(\beta_{U S, j}\right)$ and the coefficient on the interaction term of $\operatorname{Year}_{j} \times J P_{i} \times \operatorname{Tax}_{i t}\left(\beta_{J P, j}\right)$ for each year $j=2004, \ldots, 2016$. The absolute value of the estimated coefficient $\beta_{U S, j}\left(\beta_{J P, j}\right)$ is the tax semi-elasticity for US-owned (Japanese-owned) foreign subsidiaries in year $j$.

As discussed in Sections 2 and 4, because the Japanese government announced the tax reform in 2008, Japanese multinationals may have responded to the announcement and changed their profit-shifting behavior in 2008, prior to the enactment of the territorial tax regime in 2009. Thus, I search for a change in the tax semi-elasticity of the pre-tax profits of Japanese-owned foreign subsidiaries in 2008 as well as in 2009. If the hypothesis holds, the estimated coefficient for Japanese-owned subsidiaries $\left(\beta_{J P, j}\right)$ would decrease (or increase

\footnotetext{
${ }^{32}$ Altshuler et al. (2015) point out that "A notable feature of the Japanese tax environment is a compliant international tax-planning culture." (p. 24). Takashima (2009) argues that Japanese multinationals do not fully recognize the importance of international tax-planning strategies and, as a result, incur unnecessary tax costs that could be reduced by appropriate tax planning. He also notes that Euro-American multinationals view taxes as reducible and controllable costs, whereas Japanese multinationals regard them as unavoidable costs.
} 
in terms of tax semi-elasticity) relative to that for US-owned subsidiaries $\left(\beta_{U S, j}\right)$ in response to the announcement in 2008 and/or the enactment in 2009 of the territorial tax regime.

Figure 1 plots the estimated coefficients $\beta_{U S, j}$ and $\beta_{J P, j}$ in each year from 2004 to 2016. In the figure, the circles connected by the blue line indicate the estimated coefficients on host countries' tax rates from 2004 to 2016 for US-owned foreign subsidiaries, whereas the rectangles connected by the red line indicate those for Japanese-owned foreign subsidiaries. The estimated coefficients for both US- and Japanese-owned subsidiaries are negative and of similar size and tend to increase from 2004 to 2007. However, the two lines show a sudden divergence in 2008, the year when the introduction of the territorial tax reform was announced. The estimated coefficient for Japanese-owned subsidiaries sharply decreases in 2008 relative to that for US-owned subsidiaries. The tax semi-elasticity (the absolute value of the coefficient on host countries' tax rates) for Japanese-owned subsidiaries increases sharply from 0.45 in 2007 to 2.13 in 2009, whereas that for US-owned subsidiaries increases from 0.38 in 2007 to 0.86 in 2009. The estimated coefficient for Japanese-owned subsidiaries increases in 2010 but begins to decrease from 2011 to 2012 relative to that for US-owned subsidiaries.

The estimated coefficients for both US- and Japanese-owned subsidiaries exhibit an upward trend from 2015 to 2016. In particular, the coefficient for Japanese-owned subsidiaries sharply increases in 2015. However, this upward trend would not have been caused by Japan's tax reform because it was implemented six years earlier and the upward trend is observed not only for Japanese-owned subsidiaries but also for US-owned subsidiaries. It is possibly related to the international pressure to reduce profit shifting, most notably the development of the BEPS project. The OECD launched the BEPS project in 2012 to combat excessive profit shifting and tax avoidance by multinational corporations. The final report that proposed 15 BEPS action plans was released in 2015 (OECD, 2015). Japan revised its transfer pricing documentation requirements in fiscal year 2016 following the recommendations made in Action 13 and introduced the Country-by-Country Reporting system. ${ }^{33}$ The discussion of the revisions in the transfer pricing documentation requirements under the 2016 tax reform had started in fiscal year 2015. Similarly, most OECD members, including Belgium, the Czech Republic, France, Germany, Italy, Spain, the UK, and the US, introduced the Country-by-Country Reporting system in 2016. These internationally-coordinated measures against profit shifting might have influenced the reduction in the tax semi-elasticity for Japanese-owned subsidiaries experienced from 2015 to 2016.

To evaluate the statistical significance of these coefficients, Figures 2 and 3 plot, for

\footnotetext{
${ }^{33}$ This system requires Japanese multinationals to report financial information to the Japanese government on business activities in foreign countries (sales, profits, tax liabilities, and so on), which is shared with other countries' tax authorities.
} 
US- and Japanese-owned foreign subsidiaries, respectively, the estimated coefficient on the host countries' tax rates from 2004 to 2016 with $90 \%$ confidence intervals. Standard errors clustered at the subsidiary level are used to calculate the upper and lower bounds of the confidence interval. If the upper bound of the confidence interval is below zero, the estimated coefficient is negative and statistically significant at the $10 \%$ level. Figure 2 shows that the estimated coefficient for US-owned foreign subsidiaries is negative and significant at the $10 \%$ level in 2004, 2005, 2009, and 2012-2016. ${ }^{34}$ Figure 3 shows that the estimated coefficient for Japanese-owned foreign subsidiaries is negative and significant only in the years after the announcement of the territorial tax regime (2009 and 2012-2014) except for $2006 .{ }^{35}$ These patterns in the estimated coefficients suggest that the profits of Japanese-owned subsidiaries became more sensitive to the host countries' tax rates in response to the announcement and enactment of the territorial tax regime, which is consistent with the hypothesis.

As found in the previous section, tax semi-elasticity of pre-tax profits is larger for large foreign subsidiaries, which suggests that these subsidiaries are more responsive to the tax incentive for profit shifting. Thus, I examine whether the response of large Japanese-owned foreign subsidiaries to the tax reform was different from that of other subsidiaries. I split the full sample of US- and Japanese-owned foreign subsidiaries based on total assets to investigate this issue. ${ }^{36}$ Large and small subsidiaries are defined in the same way as in the previous section. I calculate the mean of total assets over the data period for each subsidiary. If the mean total assets of a subsidiary are greater than that of the median subsidiary $(16,176.9$ thousand USD), the subsidiary is classified into the large subsidiary group. Otherwise, it is classified into the small subsidiary group.

\footnotetext{
${ }^{34}$ The coefficient is statistically significant at the 5\% level for 2004, 2009, and 2015 and at the $1 \%$ level for 2005 and $2012-2014$.

${ }^{35}$ The coefficient is statistically significant at the $5 \%$ level for 2012 and at the $1 \%$ level for 2009.

${ }^{36} \mathrm{In}$ addition, I examined the heterogeneous response of Japanese-owned foreign subsidiaries to the tax reform depending on intangible intensity. However, the responses of intangible-intensive and nonintangibleintensive Japanese-owned subsidiaries were not clearly different, probably because the profit-shifting behavior of Japanese-owned foreign subsidiaries is not sufficiently sensitive to intangible intensity, as found in the previous section. Thus, these results are not discussed in the present paper.
} 
By extending equation (2), I estimate the following equation:

$$
\begin{aligned}
\ln \pi_{i t} & =\alpha_{i}+\sum_{j=2004}^{2016} \beta_{U S, j}^{L} \text { Year }_{j} \times U S_{i} \times \text { Large }_{i} \times \operatorname{Tax}_{i t}+\sum_{j=2004}^{2016} \beta_{U S, j}^{S} \text { Year }_{j} \times U S_{i} \times \text { Small }_{i} \times \text { Tax }_{i t} \\
& +\sum_{j=2004}^{2016} \beta_{J P, j}^{L} \text { Year }_{j} \times J P_{i} \times \text { Large }_{i} \times \operatorname{Tax}_{i t}+\sum_{j=2004}^{2016} \beta_{J P, j}^{S} \text { Year }_{j} \times J P_{i} \times \text { Small }_{i} \times \text { Tax }_{i t} \\
& +\sum_{j=2004}^{2016} \gamma_{U S, j}^{L} \text { Year }_{j} \times U S_{i} \times \text { Large }_{i}+\sum_{j=2004}^{2016} \gamma_{U S, j}^{S} \text { Year }_{j} \times U S_{i} \times \text { Small }_{i} \\
& +\sum_{j=2004}^{2016} \gamma_{J P, j}^{L} \text { Year }_{j} \times J P_{i} \times \text { Large }_{i}+\sum_{j=2004}^{2016} \gamma_{J P, j}^{S} Y_{\text {ear }}^{j} \times J P_{i} \times \text { Small }_{i} \\
& +\alpha_{1} \ln K_{i t}+\alpha_{2} \ln L_{i t}+\boldsymbol{X}_{i t} \gamma+\text { Industry }_{i} \times \text { Year }_{t}+u_{i t}
\end{aligned}
$$

where the dummy variable Large $_{i}$ is equal to one if subsidiary $i$ is in the large subsidiary group and zero otherwise. Similarly, the dummy variable $S m a l_{i}$ is equal to one if subsidiary $i$ is in the small subsidiary group and zero otherwise. The definitions of other variables are the same as in equation (2). This specification estimates the tax semi-elasticity of pre-tax profits, which is the absolute value of the estimated coefficient on the host country's tax rate, for four groups of foreign subsidiaries: large US-owned subsidiaries, small US-owned subsidiaries, large Japanese-owned subsidiaries, and small Japanese-owned subsidiaries in each year from 2004 to 2016. Because large subsidiaries are more responsive to the tax incentive for profit shifting, as found in the previous section, I expect that the pre-tax profits of large Japanese-owned subsidiaries would become more responsive to host countries' tax rates in response to the announcement and/or enactment of the territorial tax regime.

Figure 4 plots the estimated coefficients on host countries' tax rates for large US- and Japanese-owned foreign subsidiaries from 2004 to 2016. The circles connected by the blue line indicate the estimated coefficients on host countries' tax rates for large US-owned foreign subsidiaries from 2004 to 2016, whereas the rectangles connected by the red line indicate those for large Japanese-owned subsidiaries. Compared with Figure 1, the tax semi-elasticity for large Japanese-owned subsidiaries increases more sharply from 0.75 in 2007 to 2.78 in 2008, with a further increase to 3.15 in 2009. The tax semi-elasticity for large Japanese-owned subsidiaries is larger than that for US-owned subsidiaries from 2008 to 2012. Moreover, the gap in the estimated tax semi-elasticities between US- and Japanese-owned subsidiaries from 2008 to 2012 is larger in Figure 4 than in Figure 1. This suggests that large Japanese-owned subsidiaries responded more strongly to the announcement of the tax reform, by shifting profits to low-tax countries than did large US-owned subsidiaries. As in Figure 1, the tax 
semi-elasticity in Figure 4 decreases from 2015 to 2016 for both large US- and Japaneseowned subsidiaries in a parallel manner, which indicates the reduction is unlikely to be the consequence of Japan's 2009 tax reform.

Figure 5 plots the estimated coefficient on the host countries' tax rates from 2004 to 2016 with the $90 \%$ confidence interval for large Japanese-owned foreign subsidiaries. Standard errors clustered at the subsidiary level are used to calculate the upper and lower bounds of the confidence interval. The figure shows that the estimated coefficients for large Japaneseowned subsidiaries are small in absolute value and statistically insignificant from 2004 to 2007 but become larger and statistically significant from 2008 to 2014 (except for 2013) at the $10 \%$ level. $^{37}$

In Figure 6, I compare the estimated coefficients on host countries' tax rates for small and large Japanese-owned foreign subsidiaries. The figure implies that the sensitivity of reported profits to host-country tax rates sharply increased for large subsidiaries compared with that of small subsidiaries in 2008 and that tax semi-elasticity remained larger for large subsidiaries up until 2016, despite the tax semi-elasticity decreasing in 2015 and 2016 for both small and large foreign subsidiaries. In summary, the semi-elasticity of pre-tax profits of large Japaneseowned foreign subsidiaries with respect to host-country tax rates increased in 2008 and was larger than that of large US-owned subsidiaries until 2012 and than that of small Japaneseowned subsidiaries until 2016. This suggests that large Japanese-owned foreign subsidiaries began to shift more profit to low-tax countries in response to the announcement that the territorial tax system would be implemented than did large US- and small Japanese-owned foreign subsidiaries.

Admittedly, there is a possibility that other changes in the international tax system after 2008 affected the estimate of the tax semi-elasticity for Japanese-owned subsidiaries. In particular, the revisions in the CFC rules are the most relevant factors that could possibly influence the profit-shifting behavior of Japanese multinationals. ${ }^{38}$ When the METI proposed the territorial tax reform in an interim report (METI, 2008), it suggested that the need to tighten the CFC rules simultaneously should also be examined. However, the METI (2018) also insists that any such modifications in the CFC rules should be appropriate and minimal to avoid excessively hindering the business activities of multinationals. Indeed, although the CFC rules were modified several times after the tax reform, these modifications were minor

\footnotetext{
${ }^{37}$ The coefficients are statistically significant at the $5 \%$ level in $2008,2010,2011$, and 2014 , and at the $1 \%$ level in 2009 and 2012.

${ }^{38}$ Note that the influences of any policy changes in Japan, including the revisions in the CFC rules, on the pre-tax profits of Japanese-owned foreign subsidiaries (the dependent variable itself) are accounted for by the full set of year dummies interacted with the $J P_{i}$ dummy variable $\left(Y e a r_{j} \times J P_{i}\right)$ in equation (2), and by the triple interaction terms of $Y e a r_{j} \times J P_{i} \times \operatorname{Large}_{i}$ and $Y e a r_{j} \times J P_{i} \times S m a l l_{i}$ in equation (3).
} 
and did not clearly tighten or soften the CFC rules during the data period after 2009.

More precisely, the Japanese CFC rules set the so-called "trigger tax rate". Under the CFC rules, if a foreign subsidiary faces an effective tax rate lower than (or equal to) the trigger tax rate, the subsidiary's income would be added to the income of the Japanese parent and immediately taxed by the Japanese government. The threshold for the trigger tax rate was " $25 \%$ or less" in 2009, when Japan implemented the territorial tax reform. In 2010 , this threshold was reduced to " $20 \%$ or less". In 2015 , the threshold was changed to "less than 20\%". These modifications were intended to exempt certain multinationals from the CFC rules and were responses to the declining trend in corporate tax rates in foreign countries. Moreover, even if a subsidiary operates in a country with a tax rate lower than the trigger tax rate, the subsidiary would be exempt from the CFC regulation as long as it proves that it operates real business activities in the host country. ${ }^{39}$

In 2010, some passive foreign income became subject to Japanese taxation even if a subsidiary was exempt from immediate taxation by the CFC regulations. However, the types of passive income subject to immediate taxation were fairly limited. ${ }^{40}$ Therefore, considering that the revisions to the CFC rules were minor between 2008 and 2016, the increase in the tax semi-elasticity of pre-tax profits reported by Japanese-owned foreign subsidiaries in and after 2008 was likely to be a response to the announcement and enactment of the territorial tax regime.

\section{Alternative Specifications for Robustness Checks}

The analysis in the previous section showed that the tax semi-elasticity of the pre-tax profits of Japanese-owned foreign subsidiaries began to increase in 2008 in response to the announcement of the territorial tax regime by the METI. In particular, large Japanese-owned foreign subsidiaries were more responsive to the tax reform than were large US-owned foreign subsidiaries or small Japanese-owned foreign subsidiaries, which served as comparison groups. Figure 4 shows that, from 2015 to 2016, the tax semi-elasticities for both large US- and Japanese-owned subsidiaries decrease to the same extent, thus indicating that this reduction is unlikely to be related to the influence of the Japanese territorial tax reform.

\footnotetext{
${ }^{39}$ There are several criteria for exemption from the CFC regulation including: 1) the main business of the subsidiary is not shareholding, trade of patent rights, or lease of vessels and aircraft, 2) the subsidiary has fixed facilities (such as offices, stores, and plants) in the host country, 3) the subsidiary is controlled, managed, and operated in the host country (for example, company meetings and board meetings take place in the host country), and 4) the subsidiary's main business is held in the host country or the subsidiary trades mainly with nonrelated parties, depending on the subsidiary's main business.

${ }^{40}$ To meet the requirements from the BEPS project, the Japanese CFC rules were significantly tightened in 2017 by expanding the coverage of passive foreign income subject to immediate taxation.
} 
In this section, I adopt alternative specifications to check the robustness of these results. I examine the change in the responsiveness of pre-tax profits to host-country tax rates in 2008 by estimating the following equation for each of the US and Japanese samples separately:

$$
\begin{aligned}
\ln \pi_{i t}= & \alpha_{i}+\beta_{1} \text { Tax }_{i t}+\beta_{2} \text { After }_{t} \times \operatorname{Tax}_{i t}+\alpha_{1} \ln K_{i t}+\alpha_{2} \ln L_{i t} \\
& +\boldsymbol{X}_{i t} \boldsymbol{\gamma}+\text { Industry }_{i} \times \text { Year }_{t}+u_{i t},
\end{aligned}
$$

where After $_{t}$ is a dummy variable that is equal to one if $t \geq 2008$ and zero otherwise. The definitions of other variables are the same in equation (1). The key parameter of interest is the coefficient on the interaction term After $_{t} \times \operatorname{Tax}_{i t}\left(\beta_{2}\right)$, which captures the change in the tax semi-elasticity of pre-tax profits of foreign subsidiaries after the announcement of the territorial tax reform. As found in the previous section, if Japanese multinationals responded to the announcement of the reform by shifting more profits to low-tax subsidiaries when facing higher tax rates, the estimated coefficient on $A f \operatorname{ter}_{t} \times \operatorname{Tax}_{i t}$ is expected to be negative $\left(\beta_{2}<0\right)$. In particular, the increase in the tax semi-elasticity (the absolute value of $\beta_{2}$ ) would be larger for large Japanese-owned foreign subsidiaries than for other subsidiaries (i.e., large US-owned foreign subsidiaries and small Japanese-owned subsidiaries). To test this hypothesis, I estimate equation (4) for each of the following six subsamples: (1) all Japanese-owned subsidiaries, (2) small Japanese-owned subsidiaries, (3) large Japaneseowned subsidiaries, (4) all US-owned subsidiaries, (5) small US-owned subsidiaries, and (6) large US-owned subsidiaries. The definitions of large and small subsidiaries are the same as in the previous sections.

First, I exclude observations for 2015 and 2016 because, as found in the previous section, the tax semi-elasticities for both US- and Japanese-owned subsidiaries decreased in a similar manner for these two years for reasons that appear to be unrelated to the 2009 tax reform. Table 5 presents the estimation results. Columns (1)-(6) of the table show the results when using the subsamples (1)-(6) as described above, respectively. Columns (1)-(3) present the results for all Japanese-owned subsidiaries, small Japanese-owned subsidiaries, and large Japanese-owned subsidiaries, respectively. In column (1), the estimated coefficients on Tax $(-0.22)$ and After $_{t} \times \operatorname{Tax}_{i t}(-0.70)$ imply that the tax semi-elasticity of the pre-tax profit of the average Japanese-owned foreign subsidiary was 0.22 from 2004 to 2007 and that it increased by 0.70 from 2008 to 2014, which is consistent with the hypothesis and the finding of Figure 1, although these coefficients are not statistically significant.

In column (3) of Table 5, I find a strong profit-shifting response by large Japanese-owned subsidiaries to the tax reform. The coefficient on After $_{t} \times \operatorname{Tax}_{i t}$ is -1.51 and statistically significant at the $5 \%$ level, whereas that on $\operatorname{Tax}_{i t}$ is -0.30 , suggesting that the tax semi- 
elasticity for large Japanese-owned subsidiaries was 0.30 from 2004 to 2007 and that it increased by 1.51 from 2008 to 2014. In column (2), the coefficient on After $_{t} \times$ Tax $_{i t}$ for small subsidiaries is positive, although insignificant. These results imply that large Japanese-owned foreign subsidiaries were more responsive to the tax reform than were small Japanese-owned subsidiaries, which is consistent with the finding of Figure $6 .{ }^{41}$

Columns (4)-(6) of Table 5 present the estimation results for all US-owned subsidiaries, small US-owned subsidiaries, and large US-owned subsidiaries, respectively. In column (4), the coefficient on $\operatorname{Tax}_{i t}$ is -0.70 and statistically significant at the $5 \%$ level, whereas the coefficient on After $_{t} \times$ Tax $_{i t}$ is close to zero $(-0.02)$. This suggests that the tax semielasticity for the average US-owned subsidiaries is about 0.70 from 2004 to 2007 and that it did not change between the two periods examined, 2004-2007 and 2008-2014. Comparing the coefficients on $\operatorname{Tax}_{i t}$ between columns (1) and (4), I find that the tax semi-elasticity for Japanese-owned subsidiaries under the worldwide tax system from 2004 to 2007 is smaller (0.22) than that for US-owned subsidiaries (0.70). In Section 5, I found that, on average, over the entire data period from 2004 to 2016, the tax semi-elasticity for Japanese-owned foreign subsidiaries was smaller than that for US-owned foreign subsidiaries. These results imply that the average Japanese-owned foreign subsidiary was less sensitive to the incentive for profit shifting than was the average US-owned foreign subsidiary under the systems of worldwide taxation in place from 2004 to 2007, as well as over the data period from 2004 to 2016.

In column (6), the coefficient on After $_{t} \times \operatorname{Tax}_{i t}$ is -0.74 and statistically significant at the $5 \%$ level, suggesting that the tax semi-elasticity for large US-owned subsidiaries increased by 0.74 from 2008 to 2014. Comparing the coefficients on this interaction terms between columns (3) and (6), I find that the tax semi-elasticity for large Japanese-owned subsidiaries increased more (by 1.51) from 2008 to 2014 than did that for large US-owned subsidiaries (0.74), which is consistent with the hypothesis and the finding of Figure $4 .{ }^{42}$ These results

\footnotetext{
${ }^{41}$ I evaluate the statistical significance of the difference between the large and small subsidiary groups in terms of the change in the tax semi-elasticity after 2008 as follows. Using the sample of all Japanese-owned foreign subsidiaries from 2004 to 2014, I estimate the modified specification that includes the full set of the interaction terms of After $_{t}$, Large $_{i}$, and Tax $_{i t}$ as independent variables (using the same control variables as in Table 5). In this specification, the coefficient on the triple interaction term After $_{t} \times \operatorname{Large}_{i} \times$ Tax $_{i t}$ captures the difference in the change in the tax sensitivity of the pre-tax profits between large and small Japanese-owned subsidiaries. The estimated coefficient is -1.93 and is statistically significant at the $5 \%$ level, which is close to the difference between the coefficients on After $_{t} \times$ Tax $_{i t}$ in columns (2) and (3) in Table 5 $(-1.51-0.48=-1.99)$.

${ }^{42}$ I evaluate the statistical significance of the difference between large Japanese- and US-owned subsidiaries in terms of the change in the tax semi-elasticity after 2008 as follows. Using the sample of large Japaneseand US-owned foreign subsidiaries from 2004 to 2014, I estimate the modified specification that includes the full set of the interaction terms of After $_{t}, J P_{i}$, and Tax $_{i t}$ as independent variables (using the same control variables as in Table 5 , and $Y e a r_{j} \times J P_{i}$ and $Y e a r_{j} \times U S_{i}$ as additional control variables). In this
} 
confirm that Japanese multinationals responded to the announcement and enactment of the territorial tax regimes and that, as a result, the tax semi-elasticity for Japanese-owned subsidiaries (particularly, large subsidiaries) increased from 2008 to 2014, relative to that for large US-owned subsidiaries.

In summary, consistent with the findings in the previous section, Japanese-owned foreign subsidiaries responded to the announcement of the tax reform in 2008 and, as a result, the tax semi-elasticity for Japanese-owned foreign subsidiaries increased relative to US-owned foreign subsidiaries over the seven years from 2008 to 2014, suggesting that the switch to the territorial tax system facilitated profit shifting by Japanese multinationals. However, the caveat is that, when I include the observations for 2015 and 2016, the increase in the tax semi-elasticity for large Japanese-owned subsidiaries after 2008 is diminished because, as found in the previous section, the tax semi-elasticities for both large US- and Japanese-owned subsidiaries decreased from 2015 to 2016.

Table 6 presents the estimation results for the same specifications in Table 5, including the observations for 2015 and 2016. As in Table 5, columns (3) and (6) show the results for large Japanese- and US-owned foreign subsidiaries, respectively. The coefficient on $A$ fter $_{t} \times$ Tax $_{i t}$ in column (3) is larger $(-0.87)$ than that in column $(6)(-0.62)$ in absolute value. This still implies that the tax semi-elasticity for large Japanese-owned subsidiaries increased more than that for large US-owned subsidiaries in response to the announcement of the tax reform. However, the result is quantitatively weaker than that found in Table 5, where the data period is restricted to 2004-2014. The profit-shifting response of Japanese multinationals to the announcement of the tax reform was clear from 2008 to 2014 but substantially attenuated by other factors that affected both Japanese and US multinationals from 2015 to 2016, including, possibly, the anti-tax avoidance measures introduced or prepared by Japan, the US, and or other countries, in accordance with the requirements of the BEPS project.

\section{Conclusion}

This paper examines the sensitivity of the reported profits of Japanese multinationals in comparison with US multinationals to tax incentives for profit shifting, focusing on the host countries' corporate tax rates and Japan's implementation of the territorial tax regime. The main findings are twofold. First, I find that the profits of US-owned foreign subsidiaries are,

specification, the coefficient on the triple interaction term After $_{t} \times J P_{i} \times$ Tax $_{i t}$ captures the difference in the change in the tax sensitivity of the pre-tax profits between large Japanese and US-owned subsidiaries. The estimated coefficient is -0.70 , which is close to the difference between the coefficients on After $_{t} \times$ Tax $_{i t}$ in columns $(3)$ and $(6)$ in Table $5(=-1.51-(-0.74)=0.77)$. However, the coefficient on this triple interaction term is not statistically significant. 
on average, more sensitive to host countries' tax rates than are those of Japanese-owned foreign subsidiaries. The semi-elasticity of pre-tax profits with respect to host countries' corporate tax rates is larger for US-owned foreign subsidiaries than for Japanese-owned foreign subsidiaries over the whole study period from 2004 to 2016 and also for the period from 2004 to 2007, when both countries used the worldwide tax system. This suggests that the average Japanese-owned subsidiary engaged in profit shifting to a lesser extent than did the average US-owned subsidiary.

However, the tax semi-elasticity of pre-tax profits for Japanese-owned foreign subsidiaries, particularly large subsidiaries sharply increased in response to the announcement of the territorial tax regime in 2008, relative to that for US-owned foreign subsidiaries. As a result of this reform, the tax semi-elasticity of pre-tax profits for Japanese-owned subsidiaries was larger than that for US-owned subsidiaries from 2008 to 2012. Considering that other tax provisions that could affect the profit-shifting behavior, including the $\mathrm{CFC}$ rules, did not drastically change in Japan after the tax reform over the same period, these results imply that the introduction of the territorial tax system facilitated profit shifting by Japanese multinationals.

The caveat is that the profit-shifting response of Japanese multinationals diminished in the last two years of the data period, 2015 and 2016. The tax semi-elasticity of Japaneseowned subsidiaries decreased over these two years. This was also the case for large US-owned subsidiaries. Because the reported profits of both large US- and Japanese-owned subsidiaries suddenly became less sensitive to host countries' corporate tax rates over the two years, I considered that it was not related to Japan's 2009 territorial tax reform, but caused by other factors, possibly the international pressure on excessive profit shifting resulting from the BEPS project and/or the revisions of the international tax rules in Japan, the US, and other countries in accordance with the requirements of the BEPS project such as the introduction of the Country-by-Country Reporting system. Clarifying the causes of this phenomenon by analyzing the response of multinational corporations to the BEPS project is beyond the scope of this paper. However, it is worth noting that Japanese multinationals became more sensitive to the incentive for profit shifting for several years immediately after the announcement and implementation of the territorial tax system.

\section{References}

[1] Altshuler, Rosanne, Stephen E. Shay and Eric J. Toder. 2015. "Lessons the United States Can Learn from Other Countries' Territorial Systems for Taxing Income of Multinational Corporations." Available at http://ssrn. com/abstract=2557190. 
[2] Arena, Matteo P. and George W. Kutner. 2015. "Territorial Tax System Reform and Corporate Financial Policies." Review of Financial Studies, 28(8): 2250-2280.

[3] Barbone, Luca, Richard M. Bird, and Jaime Vázquez Caro. 2012. "The Costs of VAT: A Review of the Literature." Case Network Reports No. 106.

[4] Barrios, Salvador, Harry Huizinga, Luc Laeven, and Gaetan Nicodeme. 2012. "International Taxation and Multinational Firm Location Decisions." Journal of Public Economics, 96(11-12): 946-958.

[5] Beer, Sebastian, Ruud de Mooij, and Li Liu. 2018. "International Corporate Tax Avoidance: A Review of the Channels, Magnitudes, and Blind Spots." IMF Working Paper $\mathrm{WP} / 18 / 168$.

[6] Bradley, Sebastien, Estelle Dauchy, and Makoto Hasegawa. 2018. "Investor Valuations of Japan's Adoption of a Territorial Tax Regime: Quantifying the Direct and Competitive Effects of International Tax Reform." International Tax and Public Finance, 25(3): 581-630.

[7] Clausing, Kimberly A. 2003. "Tax-motivated Transfer Pricing and US Intrafirm Trade Prices." Journal of Public Economics, 87(910): 2207-2223.

[8] Clausing, Kimberly A. 2019. "Profit Shifting Before and After the Tax Cuts and Jobs Act." Available at SSRN: https://ssrn.com/abstract=3274827.

[9] Cristea, Anca D. and Daniel X. Nguyen. 2016. "Transfer Pricing by Multinational Firms: New Evidence from Foreign Firm Ownerships." American Economic Journal: Economic Policy, 8(3): 170-202.

[10] Desai, Mihir A., C. Fritz Foley, James R. Hines Jr. 2004. "A Multinational Perspective on Capital Structure Choice and Internal Capital Markets." Journal of Finance, 59(6): 2451-2487.

[11] Dharmapala, Dhammika. 2014. "What Do We Know about Base Erosion and Profit Shifting? A Review of the Empirical Literature." Fiscal Studies, 35(4): 421-448.

[12] Dharmapala, Dhammika. 2018. "The Consequences of the TCJA's International Provisions: Lessons from Existing Research." University of Chicago Coase-Sandor Institute for Law \& Economics Research Paper No. 856.

[13] Dharmapala, Dhammika and Nadine Riedel. 2013. "Earnings Shocks and Tax-motivated Income-shifting: Evidence from European Multinationals." Journal of Public Economics, 97: 95-107. 
[14] Dischinger, Matthias, Bodo Knoll, and Nadine Riedel. 2014. "The Role of Headquarters in Multinational Profit Shifting Strategies." International Tax and Public Finance, 21(2): 248-271.

[15] Dischinger, Matthias, and Nadine Riedel. 2011. "Corporate Taxes and the Location of Intangible Assets within Multinational Firms." Journal of Public Economics, 95(7): 691-707.

[16] Dowd, Tim, Paul Landefeld, and Anne Moore. 2017. "Profit Shifting of US Multinationals." Journal of Public Economics, 148: 1-13.

[17] Egger, Peter, Valeria Merlo, Martin Ruf, and Georg Wamser. 2015. "Consequences of the New UK Tax Exemption System: Evidence from Micro-Level Data." Economic Journal, 125(589): 1764-1789.

[18] Feld, Lars P., Martin Ruf, Uwe Scheuering, Ulrich Schreiber, and Johannes Voget. 2016. "Repatriation Taxes and Outbound M\&As." Journal of Public Economics, 139: 1327.

[19] Grubert, Harry and John Mutti. 1991. "Taxes, Tariffs and Transfer Pricing in Multinational Corporate Decision Making." Review of Economics and Statistics, 73(2): $285-293$.

[20] Hasegawa, Makoto and Kozo Kiyota. 2017. "The Effect of Moving to a Territorial Tax System on Profit Repatriation: Evidence from Japan." Journal of Public Economics, 153: $92-110$.

[21] Heckemeyer, Jost H. and Michael Overesch. 2017. "Multinationals' Profit Response to Tax Differentials: Effect Size and Shifting Channels." Canadian Journal of Economics, 50(4): 965-994.

[22] Hines, James R. Jr. 1999. "Lessons from Behavioral Responses to International Taxation." National Tax Journal, 52(2): 305-322.

[23] Hines, James R. Jr. 2001. "Tax Sparing and Direct Investment in Developing Countries." In James R. Hines Jr. (ed), International Taxation and Multinational Activity. Chicago: University of Chicago Press, 39-66.

[24] Hines, James R. Jr. and Eric M. Rice. 1994. "Fiscal Paradise: Foreign Tax Havens and American Business." Quarterly Journal of Economics, 109(1): 149-182.

[25] Huizinga, Harry and Luc Laeven. 2008. "International Profit Shifting within Multinationals: A Multi-Country Perspective." Journal of Public Economics, 92(5-6): 1164-1182. 
[26] Huizinga, Harry, Luc Laeven, and Gaetan Nicodeme. 2008. "Capital Structure and International Debt Shifting." Journal of Financial Economics, 88(1): 80-118.

[27] Langenmayr, Dominika and Li Liu. 2019. "Where Does Multinational Profit Go with Territorial Taxation: Evidence from the UK." Working Paper.

[28] Liu, Li. forthcoming. "Where Does Multinational Investment Go with Territorial Taxation? Evidence from the UK." American Economic Journal: Economic Policy.

[29] Liu, Li, Tim Schmidt-Eisenlohr, and Dongxian Guo. forthcoming. "International Transfer Pricing and Tax Avoidance: Evidence from Linked Trade-Tax Statistics in the UK." Review of Economics and Statistics.

[30] Markle, Kevin. 2016. "A Comparison of the Tax-Motivated Income Shifting of Multinationals in Territorial and Worldwide Countries." Contemporary Accounting Research, 33(1): $7-43$.

[31] Ministry of Economy, Trade and Industry of Japan (METI). 2008. Repatriations of Foreign Profits by Japanese Enterprises: Toward the Introduction of a Dividend Exemption System (Wagakuni Kigyo no Kaigairieki no Kanryu nitsuite). August 22, (In Japanese).

[32] Organisation for Economic Co-operation and Development (OECD). 2015. Final BEPS Package for Reform of the International Tax System to Tackle Tax Avoidance. Available at http://www.oecd.org/ctp/beps-2015-final-reports.htm.

[33] Riedel, Nadine, Theresa Lohse, and Patricia Hofmann. 2015. "Do Transfer Pricing Laws Limit International Income Shifting? Evidence from Europe." Working Paper.

[34] Saunders-Scott, Molly J. 2015. "Substitution across Methods of Profit Shifting." National Tax Journal, 68(4): 1099-1120.

[35] Slemrod, Joel. 2004. "Are Corporate Tax Rates, or Countries, Converging?" Journal of Public Economics, 88(6): 1169-1186.

[36] Takashima, Kennichi. 2009. "The Basics of International Tax and Accounting Strategies: The Importance of International Tax and Accounting Strategies for Business Operation (Kokusai Zeimu Senryaku no Kiso: Keiei Senryaku niokeru Kokusai Zeimu no Juyosei)." Zeimu Koho, 57(7): 143-151. (In Japanese)

[37] Xing, Jing. 2018. "Territorial Tax System Reform and Multinationals' Foreign Cash Holdings: New Evidence from Japan." Journal of Corporate Finance, 49: 252-282. 
Table 1: Distribution of Foreign Subsidiaries of US and Japanese Multinationals

\begin{tabular}{|c|c|c|}
\hline Country & US-owned Subsidiaries & JP-owned Subsidiaries \\
\hline Algeria & 6 & 4 \\
\hline Australia & 8 & 6 \\
\hline Austria & 1040 & 309 \\
\hline Belgium & 5338 & 1632 \\
\hline Bosnia and Herzegovina & 103 & 4 \\
\hline Bulgaria & 713 & 45 \\
\hline Canary Islands (Spain) & 9 & 37 \\
\hline Croatia & 11 & 0 \\
\hline Czech Republic & 3473 & 1371 \\
\hline Denmark & 811 & 180 \\
\hline Estonia & 392 & 65 \\
\hline Finland & 1618 & 441 \\
\hline France & 14897 & 4095 \\
\hline Germany & 8796 & 4403 \\
\hline Hungary & 599 & 308 \\
\hline Iceland & 5 & 0 \\
\hline India & 287 & 183 \\
\hline Ireland & 1890 & 230 \\
\hline Italy & 3774 & 1203 \\
\hline Japan & 29 & \\
\hline Luxembourg & 556 & 73 \\
\hline Montenegro & 0 & 10 \\
\hline Netherlands & 1744 & 631 \\
\hline New Zealand & 149 & 60 \\
\hline Norway & 1847 & 409 \\
\hline Pakistan & 29 & 31 \\
\hline Poland & 2827 & 847 \\
\hline Portugal & 1276 & 347 \\
\hline Republic of Korea & 1547 & 1818 \\
\hline Romania & 2589 & 257 \\
\hline Serbia & 1232 & 95 \\
\hline Slovakia & 1044 & 355 \\
\hline Slovenia & 332 & 97 \\
\hline Spain & 7598 & 1978 \\
\hline Sri Lanka & 0 & 2 \\
\hline Sweden & 2724 & 516 \\
\hline Thailand & 0 & 6 \\
\hline Ukraine & 680 & 41 \\
\hline United Kingdom & 27210 & 6536 \\
\hline
\end{tabular}


Table 2: Summary Statistics

\begin{tabular}{|c|c|c|c|c|}
\hline Variable & Mean & Std. Dev. & Median & $\bar{N}$ \\
\hline \multicolumn{5}{|l|}{ US-owned Foreign Subsidiaries } \\
\hline Log of Pre-tax Profit (thousand USD) & 7.16 & 2.22 & 7.29 & 77945 \\
\hline $\operatorname{Tax}_{i t}$ & .272 & .0635 & .294 & 122017 \\
\hline Log of Fixed Assets (thousand USD) & 7.32 & 3.06 & 7.43 & 100111 \\
\hline Log of Compensation (thousand USD) & 8.09 & 2.04 & 8.28 & 97464 \\
\hline Log of GDP per Capita (USD) & 10.4 & .646 & 10.6 & 122044 \\
\hline Log of Population & 17.3 & 1.06 & 17.9 & 122044 \\
\hline Unemployment Rate (\%) & 8.18 & 4.18 & 7.54 & 122044 \\
\hline GDP Growth Rate (\%) & 1.77 & 2.79 & 2.01 & 122044 \\
\hline Intangible Intensity & .0281 & .0885 & 0 & 101191 \\
\hline Total Assets (thousand USD) & 137777 & 1015083 & 13719 & 107623 \\
\hline \multicolumn{5}{|l|}{ Japanese-owned Foreign Subsidiaries } \\
\hline Log of Pre-tax Profit (thousand USD) & 7.18 & 1.91 & 7.28 & 22460 \\
\hline $\operatorname{Tax}_{i t}$ & .282 & .0574 & .295 & 34106 \\
\hline Log of Fixed Assets (thousand USD) & 7.56 & 2.65 & 7.75 & 29623 \\
\hline Log of Compensation (thousand USD) & 8.16 & 1.56 & 8.2 & 28722 \\
\hline Log of GDP per Capita (USD) & 10.4 & .578 & 10.6 & 34125 \\
\hline Log of Population & 17.4 & .999 & 17.9 & 34125 \\
\hline Unemployment Rate (\%) & 7.8 & 3.96 & 7.52 & 34125 \\
\hline GDP Growth Rate (\%) & 1.78 & 2.53 & 2.05 & 34125 \\
\hline Intangible Intensity & .0197 & .0687 & .000452 & 29540 \\
\hline Total Assets (thousand USD) & 92891 & 370270 & 19878 & 30392 \\
\hline \multicolumn{5}{|l|}{ All Foreign Subsidiaries } \\
\hline Log of Pre-tax Profit (thousand USD) & 7.17 & 2.16 & 7.29 & 100405 \\
\hline $\operatorname{Tax}_{i t}$ & .274 & .0624 & .294 & 156123 \\
\hline Log of Fixed Assets (thousand USD) & 7.37 & 2.98 & 7.51 & 129734 \\
\hline Log of Compensation (thousand USD) & 8.11 & 1.95 & 8.26 & 126186 \\
\hline Log of GDP per Capita (USD) & 10.4 & .632 & 10.6 & 156169 \\
\hline Log of Population & 17.3 & 1.05 & 17.9 & 156169 \\
\hline Unemployment Rate (\%) & 8.1 & 4.13 & 7.53 & 156169 \\
\hline GDP Growth Rate (\%) & 1.77 & 2.73 & 2.01 & 156169 \\
\hline Intangible Intensity & .0262 & .0845 & .0000464 & 130731 \\
\hline Total Assets (thousand USD) & 127893 & 913250 & 15217 & 138015 \\
\hline
\end{tabular}

Notes: $\operatorname{Tax}_{i t}$ is the corporate tax rate faced by subsidiary $i$ in year $t$. Intangible Intensity is the ratio of intangible fixed assets to total assets. 
Table 3: Tax Sensitivity of Pre-tax Profits

\begin{tabular}{|c|c|c|c|c|}
\hline & \multicolumn{2}{|c|}{ US-owned Subsidiaries } & \multicolumn{2}{|c|}{ JP-owned Subsidiaries } \\
\hline & (1) & $(2)$ & (3) & $(4)$ \\
\hline $\operatorname{Tax}_{i t}$ & $-1.0305^{* * *}$ & $-0.7392^{* * *}$ & $-1.1844^{* *}$ & -0.2811 \\
\hline & $(0.2730)$ & $(0.2784)$ & $(0.4811)$ & $(0.4954)$ \\
\hline Log of Fixed Assets & $0.0955^{* * *}$ & $0.0957^{* * *}$ & $0.0662^{* * *}$ & $0.0694^{* * *}$ \\
\hline & $(0.0068)$ & $(0.0068)$ & $(0.0149)$ & $(0.0149)$ \\
\hline Log of Compensation & $0.4154^{* * *}$ & $0.4169^{* * *}$ & $0.4544^{* * *}$ & $0.4542^{* * *}$ \\
\hline & $(0.0174)$ & $(0.0177)$ & $(0.0364)$ & $(0.0371)$ \\
\hline Log of GDP per Capita & & -0.0832 & & -0.1580 \\
\hline & & $(0.0798)$ & & $(0.1431)$ \\
\hline Log of Population & & $0.7932^{*}$ & & $2.1096^{* *}$ \\
\hline & & $(0.4254)$ & & $(0.8185)$ \\
\hline Unemployment Rate & & $-0.0161^{* * *}$ & & $-0.0300 * * *$ \\
\hline & & $(0.0033)$ & & $(0.0065)$ \\
\hline GDP Growth Rate & & $0.0051^{*}$ & & $0.0315^{* * *}$ \\
\hline & & $(0.0029)$ & & $(0.0061)$ \\
\hline Observations & 70,288 & 70,288 & 21,333 & 21,333 \\
\hline Within R-squared & 0.0849 & 0.0862 & 0.0645 & 0.0705 \\
\hline Industry-Year Dummies & Yes & Yes & Yes & Yes \\
\hline Subsidiary Fixed Effects & Yes & Yes & Yes & Yes \\
\hline
\end{tabular}

Notes: $\operatorname{Tax}_{i t}$ is the corporate tax rate faced by subsidiary $i$ in year $t$.

Standard errors clustered at the subsidiary level are in parentheses. ${ }^{* * *}$, **, and ${ }^{*}$ denote significance at the $1 \%, 5 \%$, and $10 \%$ level, respectively. 
Table 4: Heterogeneous Tax Sensitivity Depending on Intangible Intensity and Firm Size

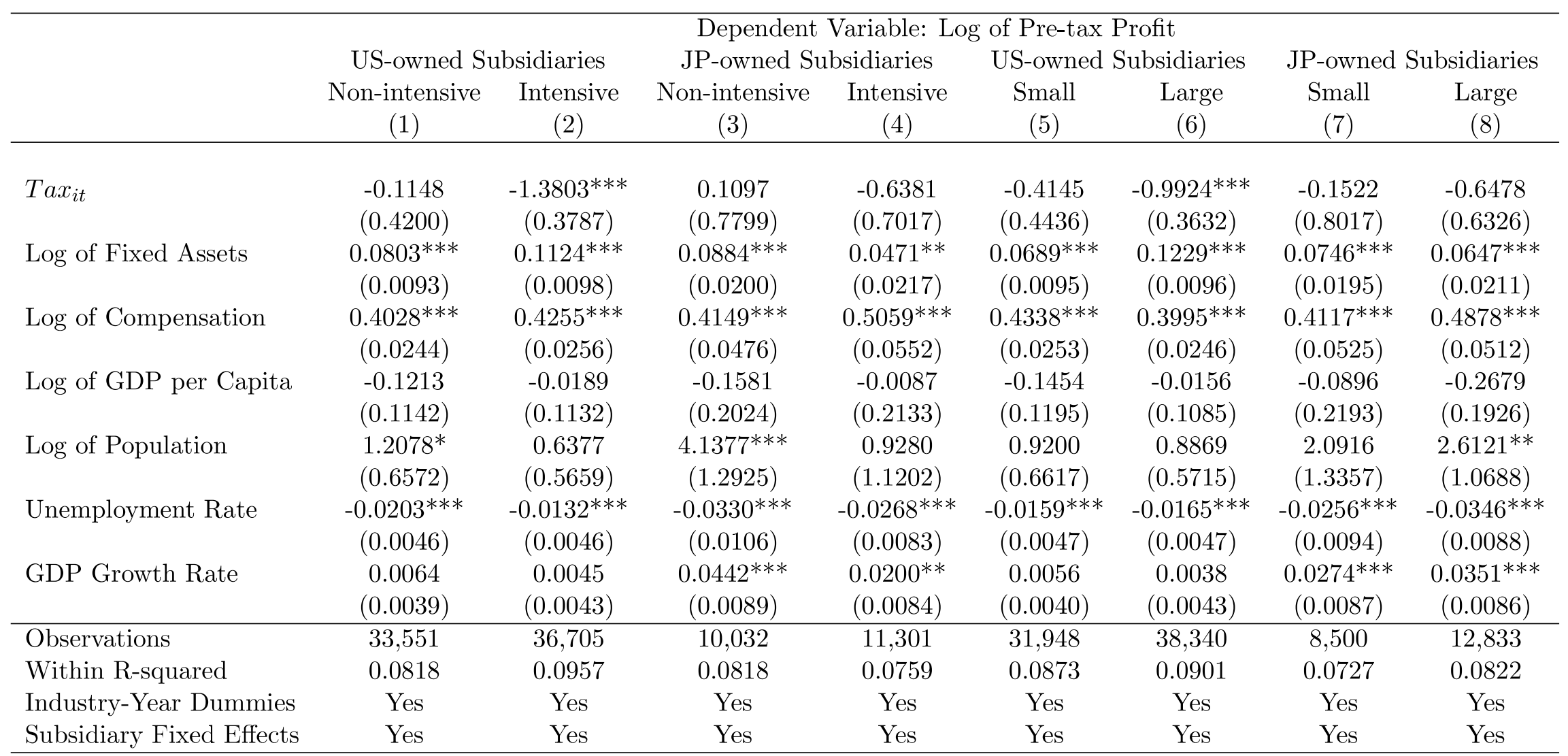

Notes: $\operatorname{Tax}_{i t}$ is the corporate tax rate faced by subsidiary $i$ in year $t$. The subsidiary's intangible intensity is defined as the mean of intangible intensities (the ratio of intangible fixed assets to total assets) over the sample period. Intangible intensive subsidiaries are defined as subsidiaries with mean intangible intensities that exceed 0.0014 (the median subsidiary's intangible intensity for the full sample). Other subsidiaries are classified as nonintangible-intensive subsidiaries. The subsidiary size is defined as the mean of total assets over the sample period. Large subsidiaries are defined as subsidiaries with mean total assets that exceed 16176.9 thousand USD (the median subsidiary size for the full sample). Other subsidiaries are classified as small subsidiaries. Standard errors clustered at the subsidiary level are in parentheses. $* * *, * *$, and $*$ denote significance at the $1 \%, 5 \%$, and $10 \%$ level, respectively. 
Table 5: Change in Tax Sensitivity after the Announcement of the Tax Reform (Data Period: 2004-2014)

\begin{tabular}{|c|c|c|c|c|c|c|}
\hline & \multicolumn{6}{|c|}{ Dependent Variable: Log of Pre-tax Profit } \\
\hline & \multicolumn{3}{|c|}{ JP-owned Subsidiaries } & \multicolumn{3}{|c|}{ US-owned Subsidiaries } \\
\hline & $\begin{array}{l}\text { All } \\
(1)\end{array}$ & $\begin{array}{c}\text { Small } \\
(2)\end{array}$ & $\begin{array}{c}\text { Large } \\
(3)\end{array}$ & $\begin{array}{l}\text { All } \\
(4)\end{array}$ & $\begin{array}{c}\text { Small } \\
(5)\end{array}$ & $\begin{array}{c}\text { Large } \\
(6)\end{array}$ \\
\hline \multirow[t]{2}{*}{$\operatorname{Tax}_{i t}$} & -0.2205 & -0.3982 & -0.2997 & $-0.7023^{* *}$ & -0.6107 & -0.5194 \\
\hline & $(0.5452)$ & $(0.8551)$ & $(0.7324)$ & $(0.3121)$ & $(0.5014)$ & $(0.4120)$ \\
\hline \multirow{2}{*}{ After $_{t} \times \operatorname{Tax}_{i t}$} & -0.7023 & 0.4843 & $-1.5107^{* *}$ & -0.0170 & 0.5008 & $-0.7443^{* *}$ \\
\hline & $(0.4425)$ & $(0.6371)$ & $(0.6598)$ & $(0.2244)$ & $(0.3181)$ & $(0.3312)$ \\
\hline \multirow[t]{2}{*}{ Log of Fixed Assets } & $0.0651^{* * *}$ & $0.0718^{* * *}$ & $0.0604^{* * *}$ & $0.0879^{* * *}$ & $0.0638^{* * *}$ & $0.1127^{* * *}$ \\
\hline & $(0.0155)$ & $(0.0210)$ & $(0.0215)$ & $(0.0076)$ & $(0.0112)$ & $(0.0105)$ \\
\hline \multirow[t]{2}{*}{ Log of Compensation } & $0.4445^{* * *}$ & $0.3860 * * *$ & $0.4878^{* * *}$ & $0.3988^{* * *}$ & $0.4100 * * *$ & $0.3869^{* * *}$ \\
\hline & $(0.0399)$ & $(0.0539)$ & $(0.0559)$ & $(0.0192)$ & $(0.0280)$ & $(0.0261)$ \\
\hline \multirow[t]{2}{*}{ Log of GDP per Capita } & -0.2510 & -0.0272 & $-0.4172^{*}$ & -0.0624 & 0.0110 & -0.0681 \\
\hline & $(0.1643)$ & $(0.2654)$ & $(0.2158)$ & $(0.0886)$ & $(0.1323)$ & $(0.1201)$ \\
\hline \multirow[t]{2}{*}{ Log of Population } & $3.1111^{* * *}$ & $3.1621^{* *}$ & $3.2795^{* * *}$ & $1.1418^{* *}$ & $1.7706^{* *}$ & 0.5509 \\
\hline & $(0.9273)$ & $(1.4904)$ & $(1.2614)$ & $(0.4716)$ & $(0.7385)$ & $(0.6290)$ \\
\hline \multirow[t]{2}{*}{ Unemployment Rate } & $-0.0349 * * *$ & $-0.0295^{* * *}$ & $-0.0393^{* * *}$ & $-0.0165^{* * *}$ & $-0.0182^{* * *}$ & $-0.0144^{* * *}$ \\
\hline & $(0.0071)$ & $(0.0103)$ & $(0.0100)$ & $(0.0035)$ & $(0.0050)$ & $(0.0050)$ \\
\hline \multirow[t]{2}{*}{ GDP Growth Rate } & $0.0337 * * *$ & $0.0269^{* *}$ & $0.0386^{* * *}$ & $0.0068^{*}$ & 0.0012 & $0.0133^{* *}$ \\
\hline & $(0.0071)$ & $(0.0107)$ & $(0.0097)$ & $(0.0037)$ & $(0.0049)$ & $(0.0055)$ \\
\hline Observations & 18,422 & 7,363 & 11,059 & 60,609 & 27,650 & 32,959 \\
\hline Within R-squared & 0.0709 & 0.0716 & 0.0848 & 0.0793 & 0.0804 & 0.0837 \\
\hline Number of subid & 2,520 & 1,067 & 1,453 & 8,669 & 4,347 & 4,322 \\
\hline Industry-Year Dummies & Yes & Yes & Yes & Yes & Yes & Yes \\
\hline Subsidiary Fixed Effects & Yes & Yes & Yes & Yes & Yes & Yes \\
\hline
\end{tabular}

Notes: Tax $_{i t}$ is the corporate tax rate faced by subsidiary $i$ in year $t$. After $t$ is a dummy variable that is equal to one if $t \geq 2008$ and zero otherwise. The subsidiary size is defined as the mean of total assets over the sample period. Large subsidiaries are defined as subsidiaries with mean total assets that exceed 16176.9 thousand USD (the median subsidiary size for the full sample). Other subsidiaries are classified as small subsidiaries. Standard errors clustered at the subsidiary level are in parentheses. ***, **, and * denote significance at the $1 \%, 5 \%$, and $10 \%$ level, respectively. 
Table 6: Change in Tax Sensitivity after the Announcement of the Tax Reform (Data Period: 2004-2016)

\begin{tabular}{|c|c|c|c|c|c|c|}
\hline & \multicolumn{6}{|c|}{ Dependent Variable: Log of Pre-tax Profit } \\
\hline & \multicolumn{3}{|c|}{ JP-owned Subsidiaries } & \multicolumn{3}{|c|}{ US-owned Subsidiaries } \\
\hline & $\begin{array}{l}\text { All } \\
(1)\end{array}$ & $\begin{array}{l}\text { Small } \\
(2)\end{array}$ & $\begin{array}{c}\text { Large } \\
(3)\end{array}$ & $\begin{array}{l}\text { All } \\
(4)\end{array}$ & $\begin{array}{c}\text { Small } \\
(5)\end{array}$ & $\begin{array}{l}\text { Large } \\
\quad(6)\end{array}$ \\
\hline $\operatorname{Tax}_{i t}$ & $\begin{array}{l}-0.1933 \\
(0.5272)\end{array}$ & $\begin{array}{l}-0.5660 \\
(0.8253)\end{array}$ & $\begin{array}{l}-0.1508 \\
(0.7098)\end{array}$ & $\begin{array}{c}-0.7497^{* *} \\
(0.3043)\end{array}$ & $\begin{array}{l}-0.7311 \\
(0.4817)\end{array}$ & $\begin{array}{l}-0.6217 \\
(0.4104)\end{array}$ \\
\hline $\operatorname{After}_{t} \times \operatorname{Tax}_{i t}$ & $\begin{array}{l}-0.1761 \\
(0.4274)\end{array}$ & $\begin{array}{c}0.8983 \\
(0.6234)\end{array}$ & $\begin{array}{l}-0.8658 \\
(0.6271)\end{array}$ & $\begin{array}{c}0.0179 \\
(0.2221)\end{array}$ & $\begin{array}{c}0.5121 \\
(0.3136)\end{array}$ & $\begin{array}{l}-0.6157^{*} \\
(0.3294)\end{array}$ \\
\hline Log of Fixed Assets & $\begin{array}{c}0.0695 * * * \\
(0.0149)\end{array}$ & $\begin{array}{c}0.0738^{* * *} \\
(0.0195)\end{array}$ & $\begin{array}{c}0.0649 * * * \\
(0.0211)\end{array}$ & $\begin{array}{c}0.0957^{* * *} \\
(0.0068)\end{array}$ & $\begin{array}{c}0.0689 * * * \\
(0.0095)\end{array}$ & $\begin{array}{c}0.1228^{* * *} \\
(0.0096)\end{array}$ \\
\hline Log of Compensation & $\begin{array}{c}0.4542^{* * *} \\
(0.0371)\end{array}$ & $\begin{array}{c}0.4123^{* * *} \\
(0.0526)\end{array}$ & $\begin{array}{c}0.4877^{* * *} \\
(0.0510)\end{array}$ & $\begin{array}{c}0.4170 * * * \\
(0.0177)\end{array}$ & $\begin{array}{c}0.4338^{* * *} \\
(0.0253)\end{array}$ & $\begin{array}{c}0.3983^{* * *} \\
(0.0246)\end{array}$ \\
\hline Log of GDP per Capita & $\begin{array}{l}-0.1663 \\
(0.1437)\end{array}$ & $\begin{array}{l}-0.0204 \\
(0.2240)\end{array}$ & $\begin{array}{l}-0.2790 \\
(0.1923)\end{array}$ & $\begin{array}{l}-0.0817 \\
(0.0801)\end{array}$ & $\begin{array}{l}-0.0958 \\
(0.1218)\end{array}$ & $\begin{array}{l}-0.0402 \\
(0.1080)\end{array}$ \\
\hline Log of Population & $\begin{array}{l}2.0868^{* *} \\
(0.8220)\end{array}$ & $\begin{array}{c}2.0258 \\
(1.3345)\end{array}$ & $\begin{array}{l}2.3070^{* *} \\
(1.1034)\end{array}$ & $\begin{array}{l}0.7921^{*} \\
(0.4245)\end{array}$ & $\begin{array}{c}0.7652 \\
(0.6606)\end{array}$ & $\begin{array}{c}0.7740 \\
(0.5768)\end{array}$ \\
\hline Unemployment Rate & $\begin{array}{c}-0.0299 * * * \\
(0.0065)\end{array}$ & $\begin{array}{c}-0.0259 * * * \\
(0.0094)\end{array}$ & $\begin{array}{c}-0.0336^{* * *} \\
(0.0089)\end{array}$ & $\begin{array}{c}-0.0160 * * * \\
(0.0033)\end{array}$ & $\begin{array}{c}-0.0163^{* * *} \\
(0.0047)\end{array}$ & $\begin{array}{c}-0.0166^{* * *} \\
(0.0047)\end{array}$ \\
\hline GDP Growth Rate & $\begin{array}{c}0.0318^{* * *} \\
(0.0061)\end{array}$ & $\begin{array}{c}0.0256^{* * *} \\
(0.0088)\end{array}$ & $\begin{array}{c}0.0361^{* * *} \\
(0.0087)\end{array}$ & $\begin{array}{l}0.0051^{*} \\
(0.0029)\end{array}$ & $\begin{array}{c}0.0046 \\
(0.0040)\end{array}$ & $\begin{array}{c}0.0044 \\
(0.0043)\end{array}$ \\
\hline Observations & 21,333 & 8,500 & 12,833 & 70,288 & 31,948 & 38,340 \\
\hline Within R-squared & 0.0705 & 0.0731 & 0.0825 & 0.0862 & 0.0874 & 0.0903 \\
\hline Industry-Year Dummies & Yes & Yes & Yes & Yes & Yes & Yes \\
\hline Subsidiary Fixed Effects & Yes & Yes & Yes & Yes & Yes & Yes \\
\hline
\end{tabular}

Notes: Tax $_{i t}$ is the corporate tax rate faced by subsidiary $i$ in year $t$. After $t$ is a dummy variable that is equal to one if $t \geq 2008$ and zero otherwise. The subsidiary size is defined as the mean of total assets over the sample period. Large subsidiaries are defined as subsidiaries with mean total assets that exceed 16176.9 thousand USD (the median subsidiary size for the full sample). Other subsidiaries are classified as small subsidiaries. Standard errors clustered at the subsidiary level are in parentheses. $* * *, * *$, and $*$ denote significance at the $1 \%, 5 \%$, and $10 \%$ level, respectively. 
Figure 1: Tax Semi-elasticity for US- and Japanese-owned Foreign Subsidiaries from 2004 to 2016

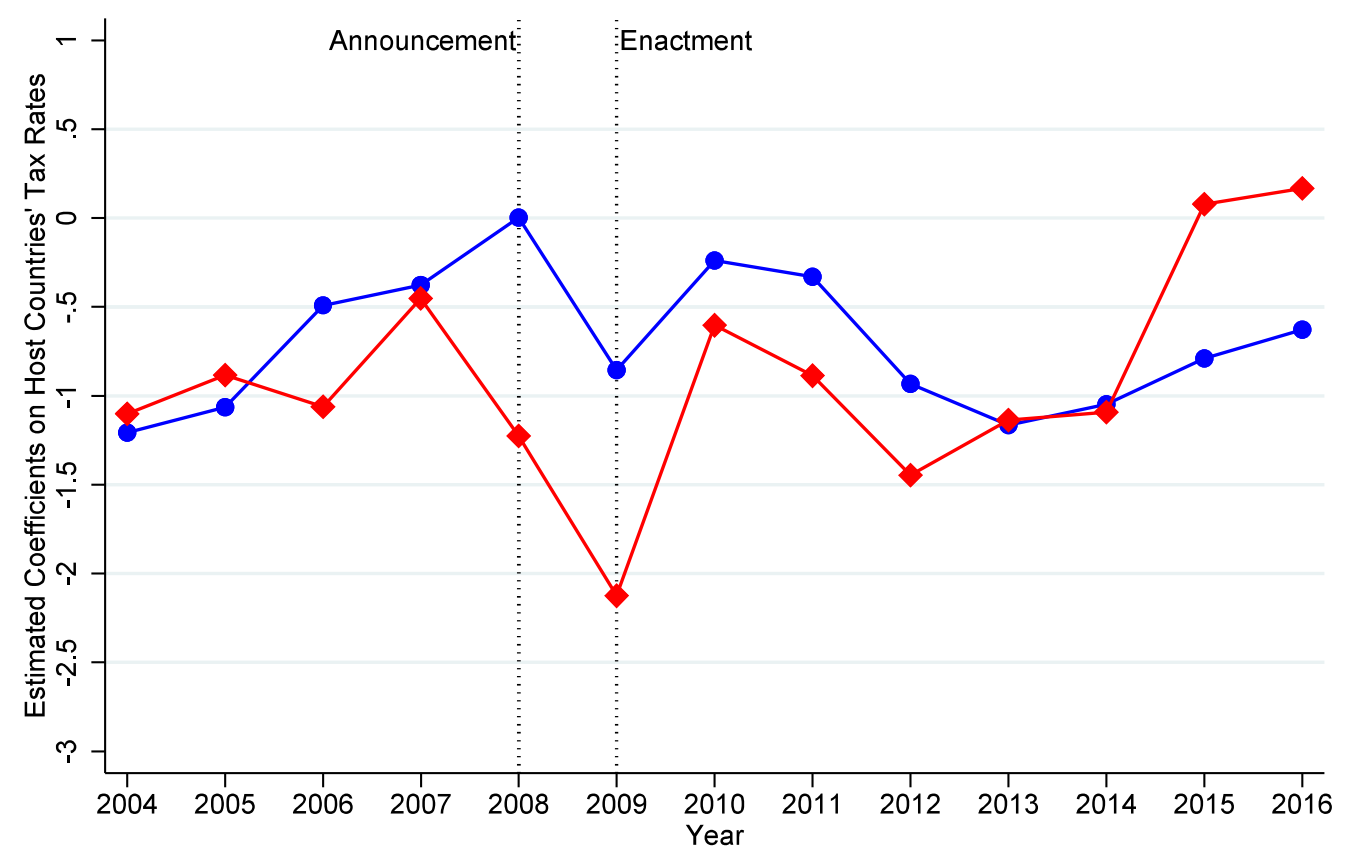

$\longrightarrow$ US-owned Subsidiaries $\longrightarrow$ JP-owned Subsidiaries

Note: This figure plots the coefficients on host countries' tax rates for US- and Japanese-owned foreign subsidiaries from 2004 to 2016 , estimated from equation (2). 
Figure 2: Tax Semi-elasticity for US-owned Foreign Subsidiaries from 2004 to 2016 with 90\% Confidence Intervals

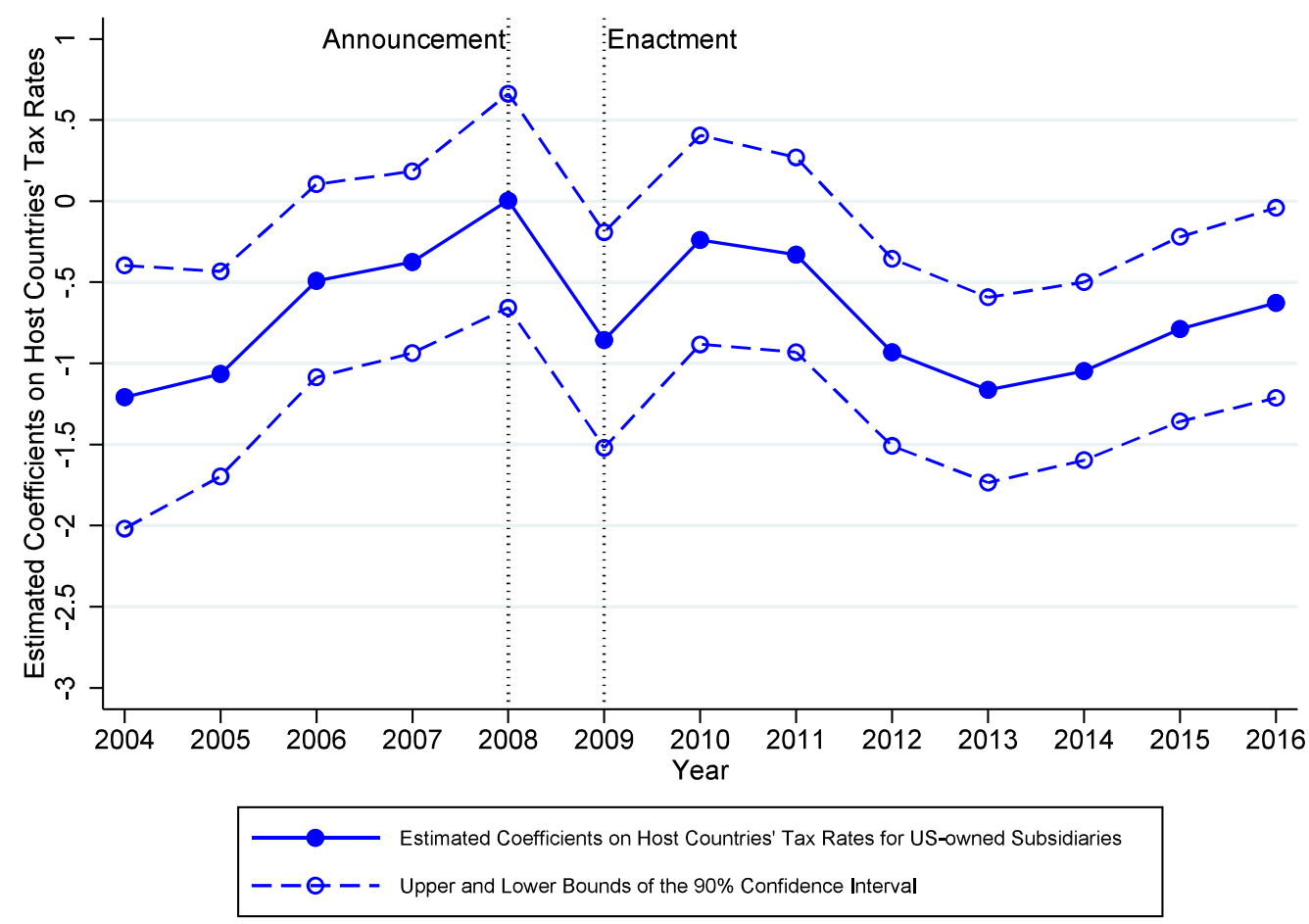

Note: This figure plots the coefficients on host countries' tax rates for US-owned foreign subsidiaries from 2004 to 2016 and their $90 \%$ confidence intervals, estimated from equation (2). Standard errors clustered by subsidiary are used when calculating the confidence intervals. 
Figure 3: Tax Semi-elasticity for Japanese-owned Foreign Subsidiaries from 2004 to 2016 with $90 \%$ Confidence Intervals

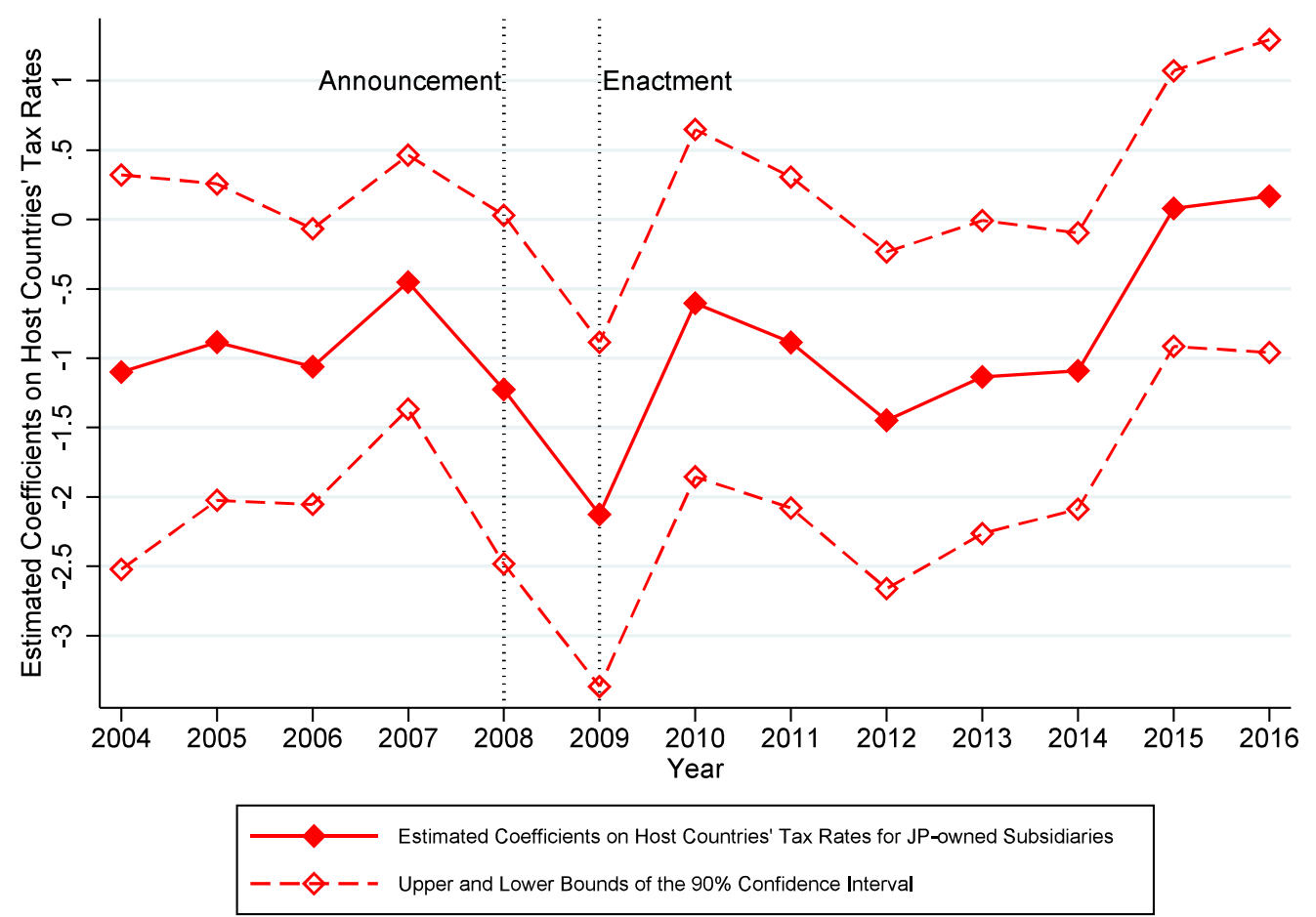

Note: This figure plots the coefficients on host countries' tax rates for Japanese-owned foreign subsidiaries and their $90 \%$ confidence intervals from 2004 to 2016, estimated from equation (2). Standard errors clustered by subsidiary are used when calculating the confidence intervals. 
Figure 4: Tax Semi-elasticity for Large US- and Japanese-owned Foreign Subsidiaries from 2004 to 2016

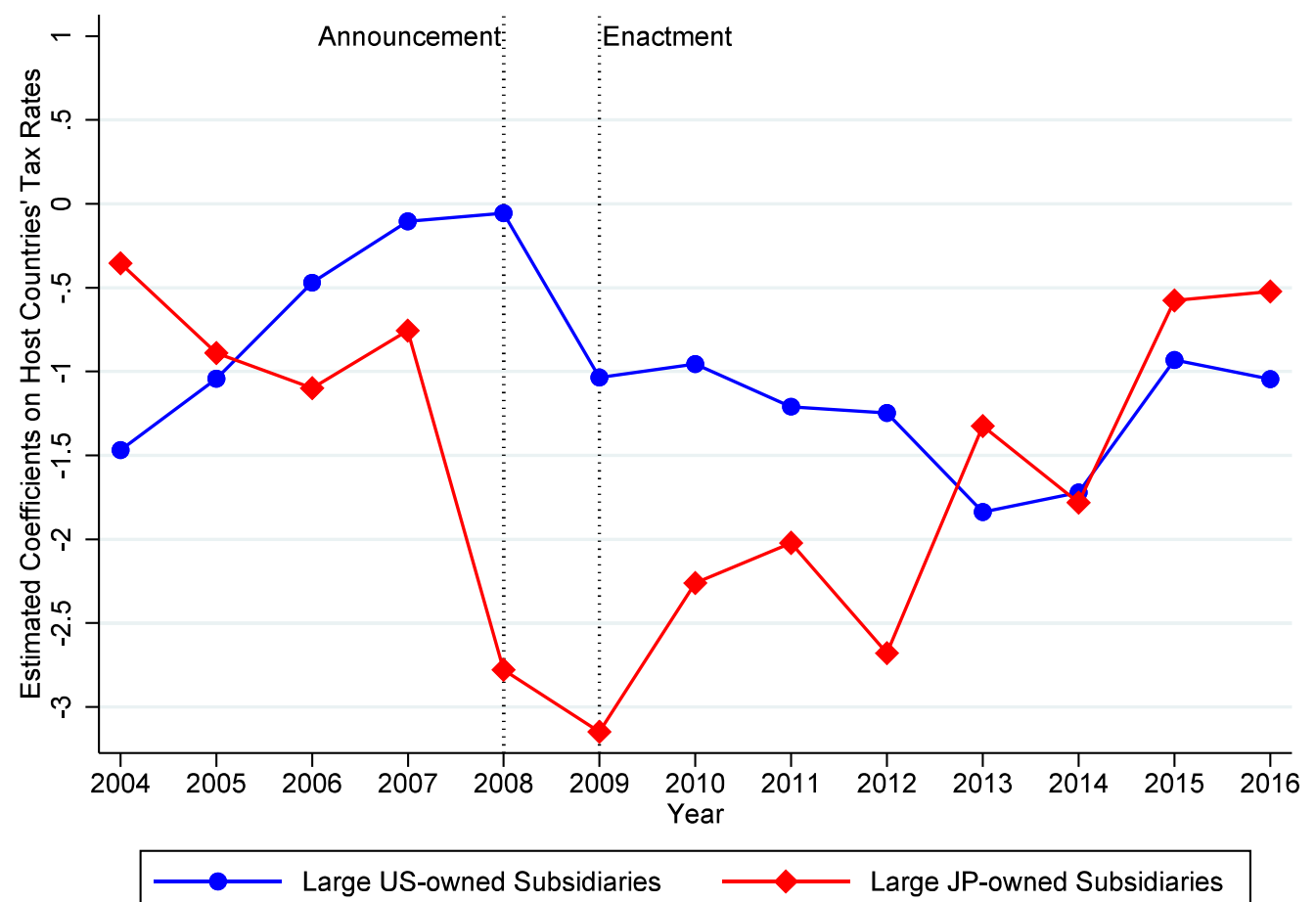

Note: This figure plots the coefficients on host countries' tax rates for large US- and Japanese-owned foreign subsidiaries from 2004 to 2016, estimated from equation (3). The subsidiary size is defined as the mean of total assets over the sample period. Large subsidiaries are defined as subsidiaries with mean total assets that exceed 16176.9 thousand USD (the median subsidiary size for the full sample). 
Figure 5: Tax Semi-elasticity for Large Japanese-owned Foreign Subsidiaries from 2004 to 2016 with $90 \%$ Confidence Intervals

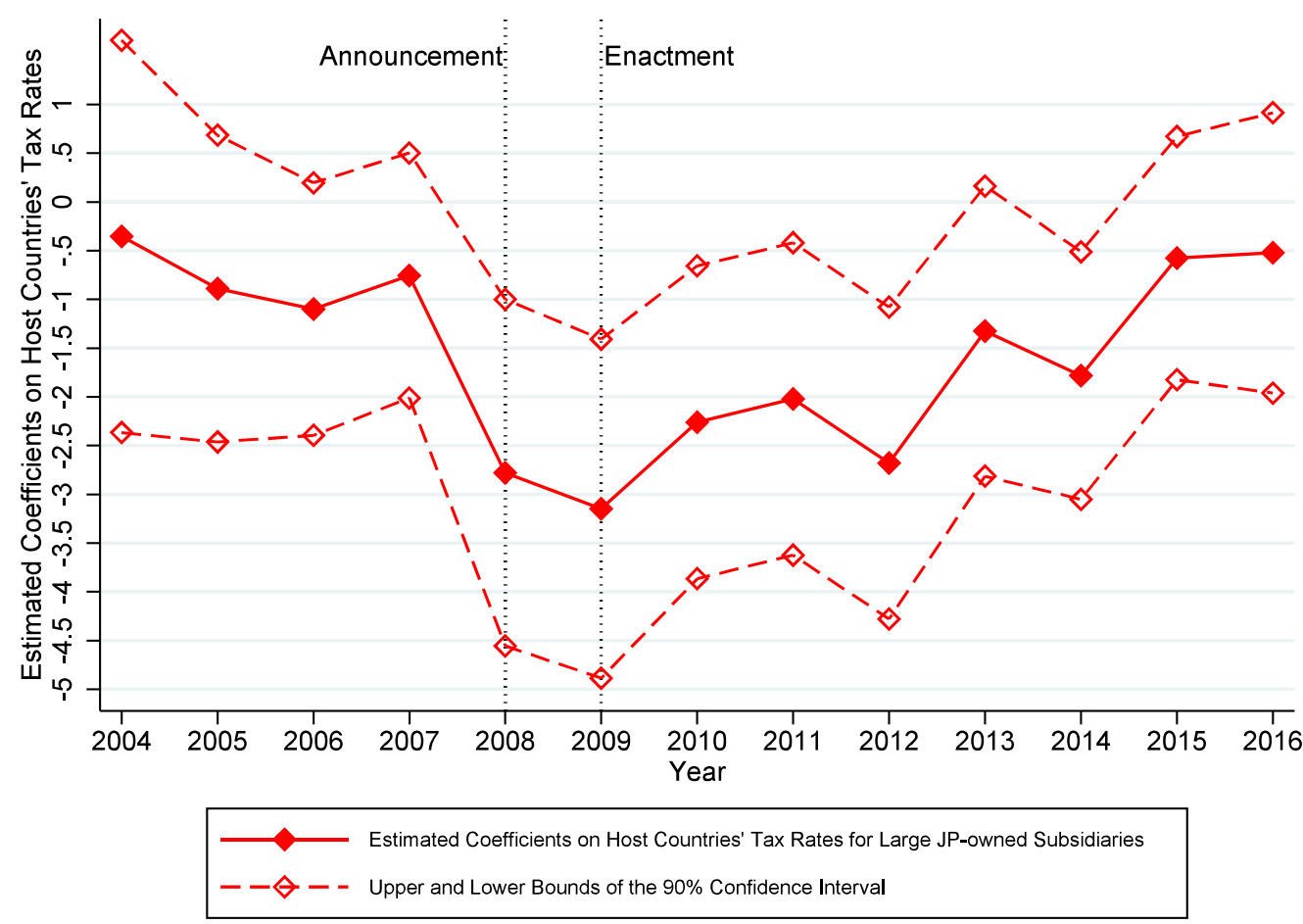

Note: This figure plots the coefficients on host countries' tax rates for large Japanese-owned foreign subsidiaries and their 90\% confidence intervals from 2004 to 2016, estimated from equation (3). The subsidiary size is defined as the mean of total assets over the sample period. Large subsidiaries are defined as subsidiaries with mean total assets that exceed 16176.9 thousand USD (the median subsidiary size for the full sample). Standard errors clustered by subsidiary are used when calculating the confidence intervals. 
Figure 6: Tax Semi-elasticity for Large and Small Japanese-owned Foreign Subsidiaries from 2004 to 2016
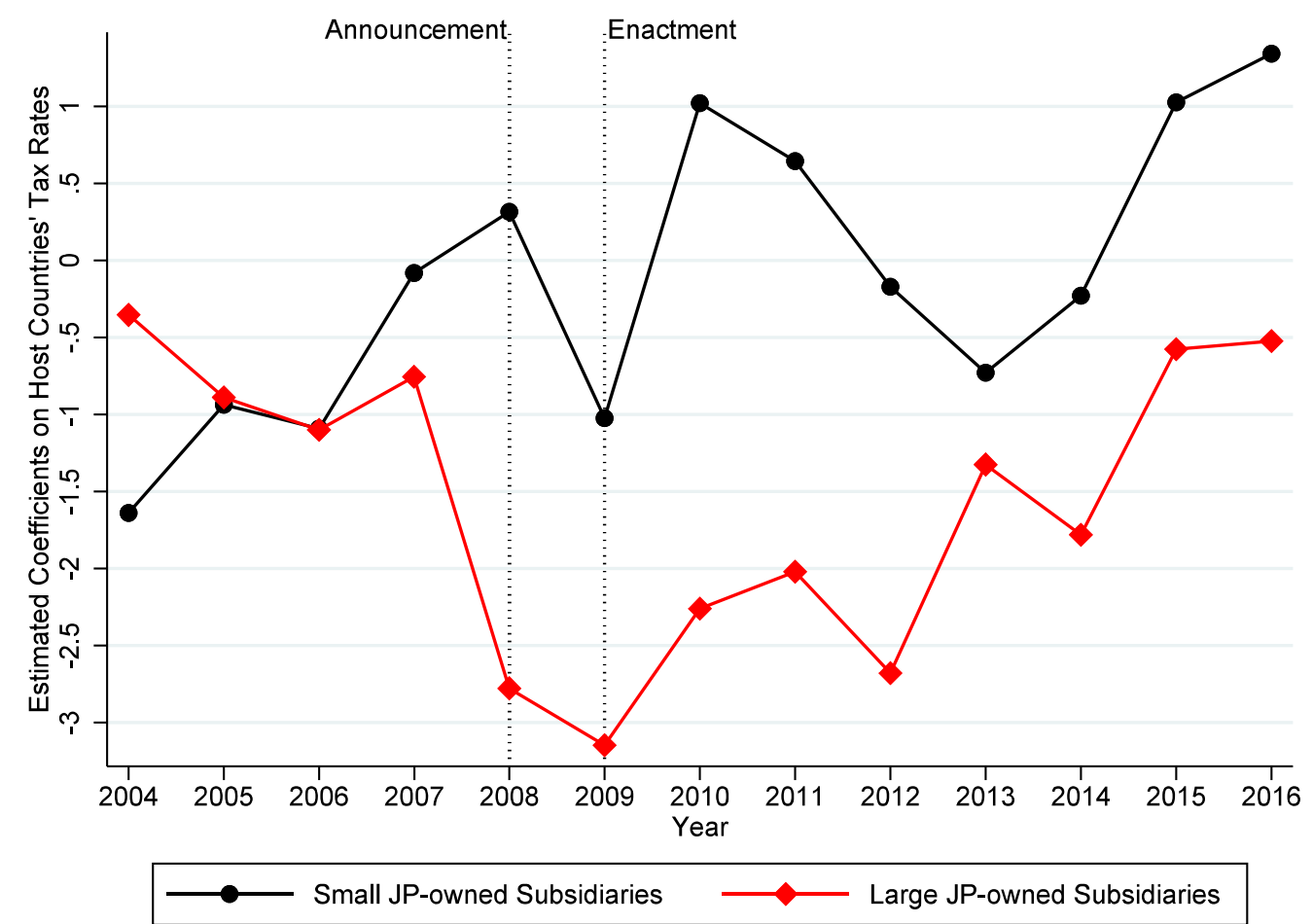

Note: This figure plots the coefficients on host countries' tax rates for small and large Japanese-owned foreign subsidiaries from 2004 to 2016, estimated from equation (3). The subsidiary size is defined as the mean of total assets over the sample period. Large subsidiaries are defined as subsidiaries with mean total assets that exceed 16176.9 thousand USD (the median subsidiary size for the full sample). Other subsidiaries are classified as small subsidiaries. 